\title{
FINANCIAL DEVELOPMENT AND ALLOCATION OF EXTERNAL FINANCE
}

\author{
Jan Bena \\ Peter Ondko
}
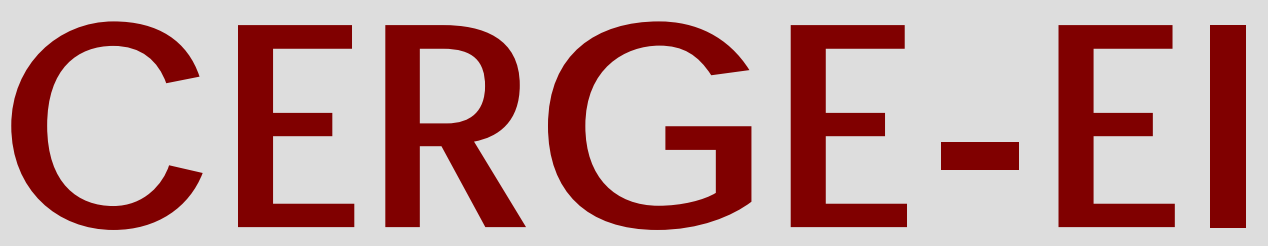

Charles University Centerfor Economic Research and Graduate Education Academy of Sciences of the Czech Republic Ec onomic s Institute 


\title{
Working Paper Series (ISSN 1211-3298)
}

\section{Financial Development and Allocation of External Finance}

\author{
Jan Bena \\ Peter Ondko
}

CERGE-EI

Prague, November 2009
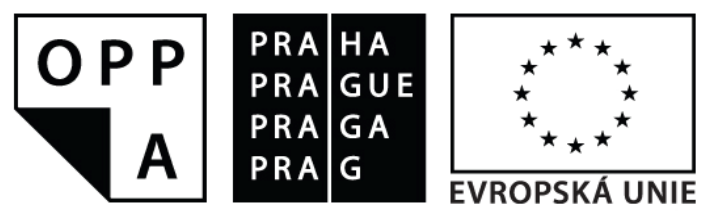

EVROPSKÝ SOCIÁLNÍ FOND

PRAHA \& EU: INVESTUJEME DO VAŠÍ BUDOUCNOSTI

Projekt je financován Evropským sociálním fondem, rozpočtem hl. města Prahy a státním rozpočtem 
ISBN 978-80-7343-200-3 (Univerzita Karlova. Centrum pro ekonomický výzkum a doktorské studium)

ISBN 978-80-7344-189-0 (Národohospodářský ústav AV ČR, v.v.i.) 


\title{
Financial Development and Allocation of External Finance*
}

\author{
Jan Bena ${ }^{\dagger} \quad$ Peter Ondko
}

November 2009

\begin{abstract}
We examine whether financial systems facilitate efficient allocation of resources into perspective projects. Employing European micro-level data from 1996-2005, we show that firms in industries with the best growth opportunities use more external finance in financially more developed countries. The result is robust to controlling for technology determinants of external finance and to choosing different proxies for growth opportunities. We also find that the explanatory power of the technology determinants decreases significantly once growth opportunities are controlled for, which suggests that the often used measures of determinants of external finance are partly driven by growth opportunities.
\end{abstract}

\begin{abstract}
Abstrakt
Táto práca skúma schopnost' finančných systémov efektívne alokovat' zdroje na perspektívne projekty. S použitím dát pokrývajúcich Európske firmy za obdobie 1996 až 2005 sme ukázali, že firmy v odvetviach s najlepšími rastovými príležitost' ami používajú viac externých finančných zdrojov v krajinách s rozvinutými finančnými trhmi. Tento výsledok je robustný na zahrnutie technologických determinantov použitia externých financií a na alternatívne spôsoby merania rastových príležitostí. Ďalej sme zistili, že vysvetl'ovacia schopnost' technologických determinantov použitia externých financií významna poklesne ak model zahŕňa aj mieru rastových príležitostí, čo implikuje, že často používané miery determinantov použitia externých financií sú čiastočne vysvetlené rastovými príležitost'ami.
\end{abstract}

Keywords: financial development, external finance, allocative efficiency JEL classification: F3, O16, G3

*We would like to thank Jan Hanousek, Štepán Jurajda and Evangelia Vourvachaki for useful comments. This research was partly supported by a research center grant No. LC542 of the Ministry of Education of the Czech Republic implemented at CERGE-EI, the joint workplace of the Center for Economic Research and Graduate Education, Charles University, Prague, and the Economics Institute of the Academy of Sciences of the Czech Republic.

†Sauder School of Business, University of British Columbia, 2053 Main Mall, Vancouver BC, V6T 1Z2, Canada, E-mail: Jan.Bena@sauder.ubc.ca.

†Corresponding author: Center for Economic Research and Graduate Education - Economic Institute (CERGE-EI), Politickych veznu 7, 11121 Praha 1, Czech Republic, E-mail: Peter.Ondko@cerge-ei.cz. 


\section{Introduction}

The key role of a financial system is to acquire information about investment opportunities and facilitate efficient allocation of resources into viable projects. ${ }^{1}$ Recent empirical work uses aggregate data to present indirect evidence of the positive capital allocation function of more developed financial markets. Wurgler (2000) estimates the effect of financial development on the elasticity of aggregate investment with respect to growth opportunities. Fisman and Love (2004) measure the effect of financial development on growth of industries with positive opportunities. ${ }^{2}$

The key process behind the ability of financial systems to allocate capital efficiently is the competence to identify firms with positive growth opportunities and channel external finance towards these firms. In this paper, we employ micro-level data to test the hypothesis of the improved capital allocation function of more developed financial markets directly on individual firms. Specifically, we ask whether firms operating in industries with positive growth shocks are more able to respond to the new opportunities by increasing their external financing in countries with higher levels of financial market development. Analyzing external finance use of individual firms instead of (industry) growth or investment rates yields a more precise test of the capital allocation efficiency hypothesis. First, we do not need to make any assumptions about how efficiently is a dollar of external finance utilized inside a firm to deliver growth. In other words, we focus on the amount of dollars raised rather than on the ultimate outcome. Second, we do not aim to explain the entire corporate investment, but only the part that is financed using external funds. If external finance is more costly than internal, firms will turn to financial markets only after they have exhausted their own resources. We explain to which extent their external finance need is satisfied by financial markets of different depth and institutional quality.

\footnotetext{
${ }^{1}$ See survey by Levine (2005) for a summary of financial systems' functions.

${ }^{2}$ We discuss how our study fits into this literature in detail in Section 2.
} 
Using a large cross-section of manufacturing firms from European countries we find that financial development improves the allocation of capital by channeling external finance to firms that operate in industries with high growth prospects. This result is robust to using two alternative proxies for the global component of industry growth opportunities: (i) industry value-added growth in the US and (ii) the change in the global industry $\mathrm{PE}$ ratios. Both proxies are based on the assumption that there exists a global component in the industry specific growth opportunities caused by demand and productivity shifts. For this reason, we focus our analysis on the manufacturing sector of a homogenous set of European countries with highly synchronized product markets and regulation where the key underlying assumption of global shocks to industry growth is arguably most likely to hold. When we proxy growth opportunities by the growth of US industries, the additional assumption is that firms in the most financially developed countries, such as the US, are financially relatively unconstrained and are able to materialize growth opportunities they encounter. When we proxy growth opportunities by the global industry $\mathrm{PE}$ ratios, we assume that financial markets are integrated to the extent that the common component of growth opportunities is priced in global industry portfolios.

Despite relying on different assumptions, both proxies yield estimates of similar economic significance. For example, if Bulgaria's banking sector were as developed as the one in Netherlands, the otherwise comparable firms that operate in an industry ranked at the 75th percentile by US growth would use 0.6 percentage points (on average per annum) more external finance in proportion to their total assets relative to the firms that operate in an industry ranked at 25 th percentile. When we approximate growth opportunities by global PE growth, we obtain the analogous estimate of 0.4 percentage points. ${ }^{3}$ The effect is more than 4 times larger if we instrument to correct for measurement error in growth counterfactuals.

We also contribute to the literature on finance-growth nexus. This literature is founded

\footnotetext{
${ }^{3}$ The sample mean of external finance use is 0.6 percent and its standard deviation is 3.8 percent.
} 
on the argument that technology employed by firms is constant across countries and determines industry-specific external finance dependence (Rajan and Zingales, 1998). We show that the ability to provide external finance $(\mathrm{EF})$ to firms in industries with the best opportunities still holds when we control for technology determinants of EF interacted with financial development. Interestingly, we find that the importance of technological determinants of EF use decreases by about 10 to $50 \%$ once growth opportunities are included in our regressions, and this is most pronounced when including a US value-added growth proxy. This suggests that the widely used measures of technological determinants of EF dependence are partly driven by growth opportunities that were financed and hence realized in countries with high financial development (such as the US).

The structure of the paper is as follows: Section 2 relates our approach to the literature, Section 3 presents the methodology, and Section 4 contains the data description. Section 5 presents the results together with robustness checks, while Section 6 summarizes our findings.

\section{Related Literature}

Theoretical models based on adverse selection or moral hazard imply that financial development improves screening of investment projects and/or enhances monitoring by external investors, which in turn leads to more efficient allocation of capital to investment projects. ${ }^{4}$ This section summarizes the empirical literature that tests this broad prediction.

In his seminal paper, Wurgler (2000) estimates the country-specific elasticities of investment to value added in order to capture the country differences in the extent to which investment increases in growing industries and decreases in declining industries. He shows that the elasticity tends to be larger in countries with larger credit markets,

\footnotetext{
${ }^{4}$ See for exmaple Boyd and Prescott (1986) for adverse selection and Townsend (1979) for moral hazard arguments.
} 
more informative stock prices, less state-ownership of firms, and greater protection of minority investors. This important result suggests a causal link from financial development to more efficient reallocation of capital. Wurgler (2000) uses industry-level gross fixed capital formation as the dependent variable as his focus is on the aggregate impact of financial system development. In our analysis, instead, we investigate the process of capital allocation directly at the micro-level and we show that firms with better growth prospects receive more external finance in more developed financial systems.

Wurgler (2000) uses realized industry-country level value added growth as a proxy for industry growth opportunities. He shows that this proxy can be justified as it is significantly positively correlated with more traditional measures of growth opportunities: average Tobin's $Q$, price-to-earnings (PE) ratio, and sales growth. Indeed, in a country with a perfectly developed financial market, realized growth is aligned with demand and productivity shocks and hence reflects growth opportunities. Also, if latent industry growth opportunities are positively autocorrelated, it is possible to use current realized growth to approximate future growth opportunities. However, it is less clear whether potential-to-realized growth correspondence holds in countries where opportunities anticipated in the past are not reflected in current growth due to financial or labor market frictions. Therefore, we use realized growth in the US (a country with high financial market development and low frictions) and price-to-earnings ratios of global industry portfolios as proxies for industry-level growth opportunities.

The reasons for choosing US growth as a measure of latent global growth opportunities are similar to Fisman and Love (2007) and Ciccone and Papaioannou (2006), who test whether investment opportunities caused by global demand and productivity shifts lead to higher growth in financially more developed countries. ${ }^{5}$ Unlike these two papers, we focus our analysis on manufacturing sectors of a homogenous set of European

\footnotetext{
${ }^{5}$ Ciccone and Papaioannou (2006) further recognize that relying on country-specific growth measures may lead to spurious conclusions due to measurement error and the possibility of systematic correlation of the country-specific component of growth opportunities with financial development.
} 
countries on a comparable level of economic development and with highly synchronized product markets where the key underlying assumption of global shocks to industry growth is arguably most likely to hold.

Alternatively, to capture the global component of growth opportunities, we use priceto-earnings (PE) ratios of world-wide industry portfolios. In contrast to the realized US industry growth, global industry PE ratios are forward-looking, based on ex-ante expectations of future growth. A high PE ratio means that investors are willing to pay a high multiple of current earnings for stocks in a given industry, which happens if they expect dividend growth.

Bekaert et al. (2007) show that under the market integration hypothesis, the global component of growth opportunities of a given industry should be competitively priced on global stock markets and reflected in the global industry's PE ratio. As a result, a country with a large share of industries with high global PE ratios should grow faster than the world economy. On the other hand, the local industry PE ratios would add information about the country's future growth only if markets are not fully integrated and the opportunities are priced locally rather than globally. The authors provide evidence in support of the hypothesis of market integration by showing that a country's industryweighted global PE ratios predict future real GDP growth, while the industry-weighted difference of local and global PE ratios doesn't have any predictive power for relative economic growth. Importantly, their analysis suggests that the PE ratio of a global industry portfolio is a valid exogenous measure of growth opportunities as it does not use local price information that could be potentially contaminated by the local level of financial development. ${ }^{6}$

Our finding that firms with positive growth prospects receive more external finance in financially more developed countries directly verifies that financial development al-

\footnotetext{
${ }^{6}$ As all European countries in our sample have their stock and banking sectors liberalized in our sample period, we do not formally test for market integration in our sample and rely on the result of Bekaert et al. (2007).
} 
leviates credit constraints. This result relates our work to firm-level structural investment model studies. Here, the optimal investment decision follows the Euler equation that trades off marginal benefits of investing today with discounted marginal costs of postponing investment to the next period. In the absence of financial constraints, the only relevant factor affecting a firm's investment decision is a project's growth potential. However, one would observe positive elasticity of investments to cash-flow if firms experience difficulties in obtaining external finance. Love (2003) and Islam and Mozumdar (2007) show that this elasticity is decreasing with financial development, which indirectly suggests a positive role of financial development in alleviating credit constraints.

Alternative tests of the role of financial system in the improvement of allocative efficiency are based on the neoclassical argument that capital should be allocated such that its marginal product is equalized across projects. This insight underlies two studies that investigate the impact of financial liberalization on capital allocation. Galindo et al. (2007) argue that a suitable approximation for marginal product of capital is either the sales to capital ratio (appropriate in the case of the Cobb-Douglas production function) or the ratio of operating profit to capital (valid under constant returns-to-scale production technology and perfect competition in output markets). They use firm-level panel data for 12 countries to create proxies for marginal product of capital and construct the efficiency index of capital allocation. Using the index, they show that efficiency increases in periods following financial liberalization. Abiad et al. (2008) approximates the expected marginal product of capital by the market-to-book ratio of publicly listed firms, the empirical equivalent of Tobin's $Q$. Next, he follows a difference-in-differences methodology to assess whether the dispersion in $Q$ s decreases in the period following liberalization. The advantage of both studies is that they aim to test simple predictions of neoclassical theory. On the other hand, the assumptions needed to form empirical proxies for the theoretical concepts are rather strong. In this respect, we complement these neoclassical approaches by avoiding an empirical approximation of marginal product of 
capital and focusing instead on the degree of alignment between growth opportunities and external finance use.

\section{Methodology}

We test the hypothesis that financial development improves efficiency of capital allocation by channeling external finance towards firms in industries with the best investment opportunities. Our regression specification is

$$
E F U_{f i c}=\alpha+\beta F D_{c} * G O_{i}+\sum_{i} \lambda_{i} D_{i}+\sum_{c} \lambda_{c} D_{c}+\gamma X_{f i c}+\varepsilon_{f i c}
$$

where $E F U_{f i c}$ is the period-average external finance use of firm $f$ from industry $i$ and country $c$ over the period 1996-2005. $F D_{c}$ denotes the country-level indicator of financial development measured as of the beginning of our sample period. $G O_{i}$ proxies global industry growth opportunities. $D_{i}$ and $D_{c}$ are industry and country fixed effects, respectively. $X_{f i c}$ is a vector of firm-level control variables.

External finance use (EFU) is computed as the sum of annual change in a shareholder's equity and change in non-current liabilities (long term debt and other noncurrent liabilities $^{7}$ ) divided by the total assets. In other words, as EFU is the difference between issuance and repayments, it captures the net increase in the use of external finance. In the appendix we show that the numerator of EFU is the balance sheet approximation of the numerator of the external finance dependence measure used by Rajan and Zingales (1998). While Rajan and Zingales (1998) use capital expenditures in the denominator, we use total assets to scale the flow of external finance. The reason is technical. Capital expenditure is a flow measure and as such it can take values very close to zero. ${ }^{8}$ Rajan and Zingales (1998) use the value of external finance dependence of the

\footnotetext{
${ }^{7}$ Other non-current liabilities comprise of liabilities with maturity longer than 1 year such as retirement benefit obligations, deferred tax liabilities, provisions, trade debts after one year and other amounts payable.

${ }^{8}$ Nilsen and Schiantarelli (2003) show that around 30\% of Norwegian plants and $6 \%$ of firms have zero
} 
industry median firm to characterize industry specific external finance dependence and, thus, they implicitly assume that capital expenditures of the median firm are positive. On the other hand, in the context of our firm-level regression with external finance use on the left-hand side, scaling by a factor that takes values close to zero would lead to excessive outliers. A measure of external financing analogous to ours has been used in firm-level panel setting in Baker et al. (2003). The summary statistics for EFU are given in Table 1. The median and the mean EFU in the sample are close to zero. This is consistent with the fact that issuance and repayments of debt and equity should be balanced on average.

To proxy for growth opportunities $G O_{i}$, we use the period-average growth rates of industries in the US. Alternatively, we use PE ratios of global industry portfolios. As there are no clear predictions whether it is the level of PE ratios or the change in the level of PE ratios that capture growth opportunities better, we use period-averages of both. As our dependent variable measures the average net additions to external finance used by a firm, a change in the level of PE ratios seems more appropriate. In the case of a balanced panel, $G O_{i}$ are computed over the whole period and are applied to all firm observations. As our panel is unbalanced, the period over which we compute the average external finance use is different across firms. To mitigate the measurement error in capturing growth opportunities, we adjust the period used to compute the growth opportunities counterfactual for every firm to match the period over which external finance is computed.

In all our specifications, we control for a set of firm-level variables, measured as of the first year a firm enters the sample. This is to eliminate the initial differences in the within-industry distributions of firms along characteristics that have potentially different effect on the use of external finance. Effectively, we are thus able to compare differences in external finance use of highly comparable firms operating in environments with varying financial development and facing different growth opportunities. The set of investment in an average year. 
firm-level characteristics included in our regression specification contains age, a dummy for being publicly listed, stock of cash and measures of the firm's leverage, asset tangibility, and size. Finally, we include the full set of industry and country dummies into our specification to control for unobservable industry and country-level factors affecting EFU.

Rajan and Zingales (1998) examine the impact of financial development on growth by investigating whether firms/industries with higher need for external finance grow faster in financially more developed countries. Presumably, the underlying mechanism behind this result is that financial development relaxes financial constraints, which matters the most for those firms that are highly dependent on external finance due to reasons related to technology specific to their type of business. Using our measure of external finance use, we are ready to directly test this mechanism. We estimate

$$
E F U_{f i c}=\alpha+\beta F D_{c} * \text { Technology } y_{i}+\sum_{i} \lambda_{i} D_{i}+\sum_{c} \lambda_{c} D_{c}+\gamma X_{f i c}+\varepsilon_{f i c}
$$

where Technology $y_{i}$ denotes industry-specific technological determinant of external finance use.

We consider three candidates for technological determinants. The first is external finance dependence (EFD), measured as in Rajan and Zingales (1998). This is an allencompassing measure of demand for external finance which is based on the assumption that in highly developed financial markets such as the US, industry differences in the observed proportion of capital expenditures financed from external sources reflect underlying technological differences among industries.

In choosing the other two technological factors, we follow Ilyina and Samaniego (2008) who suggest R\&D Intensity and Investment Lumpiness as technologically deeper determinants of external finance need. The R\&D Intensity is approximated by the average share of $R \& D$ expenditures on capital expenditures of a median firm in the US industry. Firms operating in R\&D intensive sectors may be in greater need for exter- 
nal finance, because $R \& D$ investments are often relatively large at the startup of firms or projects and they may be associated with longer gestation periods as it is likely that profits from R\&D projects materialize later.

Lastly, Investment Lumpiness is a proxy for the degree of mismatch between cash inflows and cash outflows. Firms that experience large cash-flow mismatches are more likely to seek outside financing due to a shortage of internal resources. One reason for the existence of cash-flow misalignment are investment "spikes," which are periods in which capital expenditures exceeds their usual levels. Doms and Dunne (1998) show that more than half of 12,000 US manufacturing plants in their sample experience a year in which capital stock increases by over $35 \%$ and often the spikes occur in consecutive years. From the perspective of a structural investment model, this empirical pattern suggests the existence of important non-convexities in the adjustment costs. Assuming these nonconvexities are driven by industry-specific technological factors, we calculate Investment Lumpiness as the average number of investment "spikes" in relatively frictionless US industries over a given period.

The proxies for technological determinants of finance are calculated on US data over the period under investigation, and thus they may as well be capturing underlying growth opportunity shocks specific to that period. To verify this we estimate specifications where we interact financial development with growth opportunities as well as with technological proxies:

$$
\begin{aligned}
E F U_{f i c}= & \alpha+\beta_{1} F D_{c} * G O_{i}+\beta_{2} F D_{c} * \text { Technology } \\
& +\sum_{i} \lambda_{i} D_{i}+\sum_{c} \lambda_{c} D_{c}+\gamma X_{f i c}+\varepsilon_{f i c} .
\end{aligned}
$$

If technology proxies are significantly contaminated by the growth opportunity shocks, we would expect $\beta_{2}$ to be smaller than their counterparts in specification 2 . The magnitude of this decrease should be larger when $G O_{i}$ is approximated by US Growth because 
it controls for US specific shocks which are absent in the global PE growth proxy. We expect $\beta_{1}$ to be unaffected by controlling for technological factors and to keep the magnitude estimated in specification 1.

\section{Data}

\subsection{Firm-level Data}

Firm-level panel data are obtained from Amadeus (Analyse MAjor Databases from EUropean Sources), which contains balance sheet and income statement information for a large population of public and private firms spanning all of Europe. We use the 'TOP 200 thousand' version of this database, which contains a subsample of the largest firms. Specifically, for a firm to be included in this module, at least one of the following criteria must be met: For UK, Germany, France and Italy, an operating revenue at least 15 mil. EUR, total assets at least 30 mil. EUR or number of employees at least 150. For all other countries, operating revenue at least 10 mil. EUR, total assets at least 20 mil EUR, or the number of employees at least 100.

The firm coverage is incomplete before 1996 and after 2005, and therefore we use only observations from 1996-2005. We exclude Romania from the sample due to large inconsistencies in the accounting data of its firms. Denmark and Norway have only few firms in the final sample and have been dropped too.

Our data-cleaning procedure is in line with the previous research utilizing this database. First, as in Bena and Jurajda (2007), in order to decrease the noise in average external finance use, we drop all firms for which less than 5 yearly observations of external finance use is available. As Klapper et al. (2006), we exclude firms with consolidated financial statements to avoid double counting. Further, we exclude firm-years with very small total assets (less than 1000 EUR), very high leverage (long-term debt more than double the total assets), and very large profit/loss (absolute value more than ten times the total 
assets). Additionally, we drop the bottom and top percentile of relative yearly changes in total assets in order to avoid the influence of extreme events such as mergers, acquisitions or spinoffs. We deflate all financial variables by the producer price index defined over year-country-industry triple, where industry is defined by the ISIC 2-digit. Lastly, to minimize the impact of long tails of firm size and age distributions, we exclude firms in the top percentile of the distribution by total assets, age and employment measured as of the first year the firm appears in the sample.

\subsection{Industry-level Data}

The value-added data for US used to compute our first proxy for growth opportunities are taken from OECD STAN database downloaded in 2009. We use the index of volume of value-added (VALK) for industries on the 2-digit level of ISIC rev 3.1. In some cases the volume index of value added and corresponding value-added deflator is available only for a group of two or three industries. ${ }^{9}$ In these instances we use the corresponding group deflator (VALP) to adjust nominal value-added (VALU), which is available for all industries. 10

The data for the monthly series of global PE ratios are obtained from Datastream. As of March 2008, Datastream uses Industry Classification Benchmark (ICB) created by FTSE Group and Dow Jones Indexes to classify companies into 114 sub-sectors. Following the approach of Bekaert et al. (2007), we link ICB sub-sectors into 22 manufacturing 2-digit ISIC industries. ${ }^{11}$ Whenever more than one ICB sub-sector is linked to a given 2-digit ISIC industry, we calculate the weighted average of the PE ratios of entering subsectors using their market values as weights. Finally, for every industry, we compute yearly values of the PE ratios by taking the simple mean for all months in a given year.

\footnotetext{
${ }^{9}$ Specifically these ISIC 2-digit categories: 15-16, 17-19, 32-33

${ }^{10}$ For categories 36 - Manufacturing n.e.c. and 37 - Recycling, neither volume nor nominal value-added data is available.

${ }^{11}$ We obtained the concordance table used in Bekaert et al. (2007) from the authors. However, the ICB classification has been expanded since their work. Moreover, Bekaert et al. (2007) link ICB sub-sectors to SIC industries, while we need to link them to ISIC classification.
} 
The correspondence table is available upon request.

Following Rajan and Zingales (1998) and Ilyina and Samaniego (2008) we use Compustat to compute industry-level technological determinants of the need and ability to raise external finance. Instead of using values tabulated in these papers, we re-calculate proxies for ISIC rev. 3.1 industry classification in order to be able to match them with the Amadeus data. ${ }^{12}$ In line with Rajan and Zingales (1998), we compute US Dependence on External Finance as the share of capital expenditures not financed by the cash-flow from operations. Capital expenditures is item 128 in Compustat and cash-flow from operations is defined as cash-flow from operations (item 110 or sum of items 123, 125, 126, 106, 213 and 217 if unavailable) plus change in payables (item 70 or 304 if unavailable) minus change in receivables (item 2 or 302 if unavailable) plus change in inventories (item 3 or 303 if unavailable). We sum both capital expenditures and cash-flow from operations over the 1996-2005 period for each firm and compute firm-level dependence. Industry level external finance dependence is then dependence of the median firm.

Following Ilyina and Samaniego (2008), we compute US R\&D intensity as the share of R\&D expenditures (item 46) in capital expenditures. We sum both the nominator and denominator over the 1996-2005 period for each firm and compute firm-level R\&D intensity. Again, each industry is characterized by a median firm.

US Investment Lumpiness is also computed as in Ilyina and Samaniego (2008). It is computed as the average number of investment spikes experienced by firms in a given industry over the 1996-2005 period, where an investment spike is defined as annual capital expenditure in excess of $30 \%$ of the firm's fixed assets (item 8).

The summary statistics for industry-level proxies for growth opportunities and technological determinants of external finance are presented in Table 3 and their rank correlations are presented in Tables 4 . Rank correlations of the average change of global $\mathrm{PE}$ ratios with technological determinants of external finance is significantly lower than

\footnotetext{
${ }^{12}$ We use concordance from the US census to link NAICS 2002 classification used in Compustat to 3-digit ISIC industries.
} 
comparable statistics for real value-added growth in the US, which suggests that US growth as well as technological measures are partially driven by same underlying shocks.

\subsection{Country-level Indicators of Financial Development}

We use country-level measures of financial development in order to make our results comparable with the literature. We use three traditional measures of depth of credit and stock markets, specifically private credit by deposit banks and other financial institutions to GDP, stock market capitalization to GDP and stock market total value traded to GDP. These data are taken from the 2006 version of World Bank's Financial Structure and Economic Development Database described in detail in Beck et al. (2000).

We complement measures of financial depth by a proxy for the institutional quality

of financial markets as measured by the Accounting Standards index. It rates annual reports of companies in 1990 according to the inclusion of 90 items in their balance sheets and as such it is an indicator of the quality of accounting standards. The index is produced by International Accounting and Auditing Trends (Center for International Financial Analysis and Research, Inc.) and it ranges from 0 to 90 . We scale it down by 100 before using it in regressions.

Table 2 presents summary statistics for financial development indicators. The crosscountry standard deviation is of the same order as the mean for all volume-of-financialactivity measures, which suggests substantial variation in financial development as of 1996. The variation in Accounting Standards is smaller, which is most likely caused by the lack of this data for Ireland and all countries of Central and Eastern Europe in our sample. 


\section{Results}

We present basic estimates of our main specification of equation 1 in Table 5. We report coefficients on selected regressors from regressions of the time average of annual firmlevel External Finance Use of manufacturing firms operating in the period 1996-2005 on the interaction of country-level indicators of financial development and proxies for growth opportunities of 2-digit ISIC industries. In all specifications we control for 3-digit ISIC industry and country dummies and firm-level control variables that are measured as of the first year a firm enters the sample. Specifically, for each firm we include its leverage, tangibility, collateralization, age, the number of employees, total assets, stock of cash holdings and the indicator for being publicly quoted.

The estimates in Table 5 suggest that financial development improves allocation of external finance by channeling it to industries with high growth prospects. To inspect the economic significance of our estimates we consider the effect of financial development in increasing average use of external finance for firms operating in industries at the bottom and top quartile of the industry distribution by the real value-added growth in the US. Thus, using our estimated coefficients of the interaction terms $\hat{\beta}$, we compute

$$
\hat{\beta} *\left(F D_{\max }-F D_{\min }\right) *\left(\text { USGrowth }_{75 p}-\text { USGrowth }_{25 p}\right),
$$

where $F D_{\max }$ and $F D_{\min }$ are the sample maximum and minimum of the indicator of financial development and $U S G r o w t h_{75 p}$ and $U S G r o w t h_{25 p}$ are the sample top and bottom quartiles of the real value-added growth in US, its difference being 3.3\% in the sample. The impact of the increase of Total Capitalization from its sample minimum to its sample maximum on the allocation of external finance use is then 0.36 percentage points. Thus, the difference in External Finance Use between firms operating in the industries ranked at 75 th and 25 th percentiles of US real value-added growth will be 0.36 percentage points higher in Netherlands than in Latvia, the countries with highest and lowest 
Total Capitalization in our sample, respectively. Using indicators of Private Credit, Market Capitalization, Market Value Traded and Accounting Standards we obtain economic effects of $0.56,0.16,0.31$ and 0.13 percentage points respectively. For the comparison, the sample mean and standard deviation of External Finance Use are $0.4 \%$ and $3.8 \%$, respectively. The economic significance of the financial development on the allocation of external finance may appear low, however several comments are worth noting. First, by approximating only for the industry-specific component of growth opportunities we are very restrictive. On the one hand, we alleviate endogeneity concerns but on the other we introduce measurement error which can lead to the attenuation bias. Second, we characterize each firm by the time-average of its external finance use. While this allows us to investigate the allocation of external finance across-industries over a longer period, it creates the problem of averaging net external finance to zero. We would expect firms to obtain external finance in periods of positive shocks and pay it back when returns from investments are realized, which would show as negative autocorrelation in time series of external finance use with the implication of the time average converging to zero with the length of time period.

In Panel A of Table 6, we complement estimates from Table 5, obtained using real value-added Growth of US industries as a proxy for growth opportunities, with the estimates obtained using the time-average of the level and growth in Global PE ratios as alternative proxies. We include both average level and growth in Global PE ratios to investigate whether financial development improves channeling of external finances to industries with high expectations of future growth (high level of PE ratio) or to industries in which the growth prospects increase rapidly over the investigated period (high growth of PE ratio). The results are striking; financial development makes no difference in allocating external finance to industries which differ in their average level of expected growth opportunities. On the other hand, our results suggest that financial development helps to facilitate financing of industries with growing market expectations as measured by the 
growth of Global PE ratios. Thus, we will choose Global PE Growth to be the alternative proxy for growth opportunities. The economic significance of estimates obtained with Global PE Growth is comparable to the case of US Growth. Specifically, the term from equation 4 is calculated as $0.4,0.41,0.35,0.27$, and 0.08 percentage points if financial development is measured by Total Capitalization, Private Credit, Market Capitalization, Market Value Traded and Accounting Standards, respectively.

In panel B of Table 6 we present estimates obtained on the sub-sample of EU-15 countries. Excluding countries from Central and East Europe (CEE) is justified by two reasons. First, CEE countries were still in the process of transition to a market economy and the resulting resource reallocation has been affected by their country-specific, factors of growth opportunities. Second, EU-15 countries engaged in the single product market in 1993, which presumably brought higher degree of similarity in the growth opportunities of firms operating in the same industry across different countries. Our results show that leaving out CEE countries slightly increases estimates of the coefficients of interest, irrespective of growth opportunities proxy, which is in line with the hypothesis of better synchronization of economic shocks in EU-15.

\subsection{Growth Opportunities and Technology}

The extensive literature on finance-growth nexus uses the insight of Rajan and Zingales (1998) that the causal link from finance to growth can be identified by investigating the access to finance by industries differing in their natural external finance dependence. Ilyina and Samaniego (2008) further show that the strongest technological factors underlying cross-sectional variation in external finance dependence are R\&D intensity and Investment Lumpiness. In line with these results, it is important to check whether industries dependent on external finance are actually using more of it in financially more developed countries. The results in Table 7 suggest that this is indeed the case. The coefficient on the interaction of financial development and the technological measure is 
positive and significant in most cases, with the exception of Accounting Standards. Interestingly, interactions with R\&D Intensity and Investment Lumpiness are statistically more significant in explaining improvements in the allocation of external finance caused by financial development than EFD. Again, the results are robust for the exclusion of non-EU-15 countries.

As discussed in Section 3, the differences in estimates of industrial technological determinants of dependence on external finance can be partially driven by the differences in growth opportunities over the period of their estimation. Specifically, the US specific component of growth opportunities may be the common factor driving the differences in the estimates of R\&D Intensity, Investment Lumpiness, External Finance Dependence as well as realized Value-Added Growth. This would empirically translate into higher correlation between real growth of US industries and technological determinants of finance and the decrease in the coefficients on their interactions with financial development in the regressions on actual use of external finance. For the Global PE Growth proxy for growth opportunities, this should be less of a worry as the influence of the US growth component should be limited.

Tables 4 and 8 provide evidence in line with these hypotheses. In Table 4, the spearman rank correlations between US Growth and technological determinants of finance are much higher than their counterparts for Global PE Growth. For example, the rank correlation of R\&D intensity and US growth is 0.42 with p-value 0.06 while the correlation of R\&D Intensity and Global PE Growth is only 0.06 with p-value 0.80 . A similar result is obtained for Investment Lumpiness and EFD, although in the case of the latter, the correlation with Global PE Growth rises to 0.29.

The results in Table 8 are also in line with the hypothesis of the existence of a common factor of US growth opportunities in technological determinants. The estimated coefficients on interactions of financial development and R\&D intensity and EFD drops to almost half once interactions with US Growth are included. However, we actually 
observe a drop in the estimated coefficient on interaction of financial development with US Growth once corresponding interaction with Investment Lumpiness is included in the specification.

The picture is different when we use Global PE Growth as a proxy for growth opportunities (Panel B of Table 8). The estimated coefficients on the interaction terms of financial development with Global PE Growth are statistically significant and very similar in magnitudes to their counterparts in specifications which exclude technological interactions (Table 6). Furthermore, the interactions of financial development with technological determinants in the joint specification remain statistically significant and the magnitude of the drop in the coefficients is less severe and in case of Investment Lumpiness, the estimates actually increase when compared to single-term specifications (Table 7). Summed up, the evidence suggests that the role of financial development with respect to allocation of external financing is two-fold. On the one hand, it helps to channel external finance to industries which are presumably more dependent on it due to technological reasons. On the other hand, more developed financial markets are better in providing finance to industries with greater global growth opportunities.

\subsection{Decomposing External Finance}

In Appendix A, we show that our approximation of external finance use can be decomposed into the amount of equity raised/repurchased, the amount of long-term debt issued/repaid and the change in other non-current liabilities. As there exist major contractual and institutional differences among these components of external finance, it is important to assess what is the role of financial development in the improvement of their allocation with respect to growth opportunities. To do so, we run a set of regressions equivalent to specification 1 separately using each component of external finance use as a dependent variable. We present the results of this exercise in Table 9.

Panels A and B document that financial development improves the allocation of both 
equity and long-term debt. When compared to the basic results in Table 6 , the estimated coefficients on interaction terms suggest that around one third of the improvement in allocation of external finance comes in the form of shareholder's equity, while the remaining two-thirds can be explained by long-term debt and this pattern is roughly consistent for both proxies for growth opportunities and all measures of financial development, irrespective of being a proxy for the banking sector or stock market development. For proper interpretation of these results it is important to note that the balance-sheet data we use don't allow us to distinguish the identity of the external investor. For example, long-term debt would typically consist of bank loans; however, loans from other lenders as well as issued bonds also fall into this category. Thus, composition of this category may be affected by the development of the financial sector as well. In addition, the importance of equity in the improvement of allocation of external finance is magnified by the fact that our sample consists primarily of non-listed firms that are presumably less flexible in equity issuance/repurchase.

With respect to changes in other non-current liabilities, our results suggest that financial development makes no improvement in their alignment with growth opportunities. This result is in line with the expectations given that other non-current liabilities usually consists of items such as retirement benefit obligations, deferred tax liabilities, or longterm trade debts, and thus they are components of liabilities driven primarily by factors other than the need to finance growth opportunities.

\subsection{Measurement Error}

In our analysis, we use real US Growth and Global PE Growth in 2-digit ISIC industries as proxies for the global component of growth opportunities, which introduces measurement error to our analysis. The noise present in any proxy may lead us to underestimate the coefficient of interest due to classical measurement error bias. We investigate the magnitude of bias introduced by the measurement error in two ways. First, having 
two different proxies for growth opportunities allows us to use two-stage least-squares (2SLS) approach to investigate the attenuation bias caused by measurement error. Under the assumption of the orthogonality of measurement errors in the two proxies for growth opportunities, we can use one as the instrument for the other, which allows us to use only the variation common to both of them to estimate the coefficient of interest. We use the interaction of financial development and global PE growth (US Growth) as the instrument for the interaction of financial development and US growth (global PE growth) and the results for both directions are presented in Table A.3. Compared to the basic estimates, there is a significant increase in the estimated coefficients for all measures of financial development. For example, the estimate of the coefficient on the interaction of total capitalization and global PE growth is more than 4 times higher in 2SLS than in the basic specification. In general, the order of increase of the estimates is between 2.3 to 7.5 , which suggests that the impact of the measurement error may be large. ${ }^{13}$

Second, we use a simple version of simulation-extrapolation (SIMEX) method proposed by Cook and Stefanski (1994) to assess the magnitude of attenuation bias by comparing the estimates obtained by using the set of proxies created by adding white noise of varying precision to the base measure. Specifically, for each level of standard deviation ranging from 0.005 to 0.05 , we simulate 100 draws from a multi-variate normal distribution and add them to both baseline proxies for growth opportunities. Newly created variables are then used as a proxy for growth opportunities in the interaction with the total capitalization in specification 1. Then, for each level of added noise, we compute the average of 100 obtained estimates and plot it against the standard deviation of added noise in Figure 2. The visual inspection of the plot allows us to evaluate the magnitude of the attenuation bias caused by the random error. Extrapolating back the relationship between standard error of added noise and the average estimate provides a naive guess

\footnotetext{
${ }^{13}$ Ciccone and Papaioannou (2006) carry out similar 2SLS exercise. In the industry-level growth regressions they instrument growth opportunities approximated by US growth with the world-average valueadded growth by industry controlling for the effects of financial underdevelopment. They obtain an increase in coefficients of the magnitude ranging between 3 to 6 .
} 
of how the estimate would look like if the measurement error was less severe. For example, given that the standard deviation of the US Growth proxy is 0.033 , then under the assumption that the measurement error is responsible for half of this variation, the quadratic extrapolation of the simulation results would suggest that the estimated coefficient would be approximately 0.042 , which is around $50 \%$ larger than our basic estimate.

The results obtained from the 2SLS and SIMEX exercises suggest different levels of bias caused by measurement error. Naturally, we don't have any estimate of the proportion of variance of US growth or Global PE Growth caused by measurement error. However, Figure 2 suggests that even if the measurement noise accounted for a very large proportion in the variation of US Growth or Global PE Growth, the resulting attenuation bias is not likely to be of larger magnitude than 2 , which is in contrast with the results obtained in the 2SLS exercise. A possible explanation for this discrepancy is a poor extrapolating performance of quadratic fit in the SIMEX exercise, or the existence of non-standard upward bias common to both proxies for growth opportunities, which would imply the violation of the assumption of the orthogonality of measurement errors in the 2SLS exercise. ${ }^{14}$

\subsection{Robustness Checks}

We check for the robustness of our results across several dimensions. First, as argued in Klapper et al. (2006), there exists substantial diversity in the legal forms of incorporation in Europe. The comparability of firms across countries can thus be increased by narrowing the sample to the forms of incorporation equivalent to limited and limited liability companies. In Panel A of Table A.2 we show that our results also hold for this narrow sample.

Second, in our difference-in-differences model, we regress firm-level external finance use on the industry-country group term that applies to all firms in the group. Effectively,

\footnotetext{
${ }^{14} \mathrm{An}$ upward bias common to both proxies may arise if they both approximate growth opportunities more precisely in more financially developed countries.
} 
we investigate conditional industry-country averages in external finance use and to the extent that the efficiency of this average is driven by the number of individual firms within each group, the potential concern is that our results may be affected by the industries with a small number of firms. In Panel B of Table A.2, we present the estimates of our basic specification on the sample constrained to industry-country groups with at least 20 firms. The estimates are qualitatively unaffected and the investigated effect is economically stronger.

Third, we account more carefully for the unbalanced nature of our panel. If industryspecific factors affecting external finance use have been changing rapidly over time, controlling only for industry fixed effects can be insufficient. Thus, we amend our baseline specification 1, by interacting industry fixed effects with period fixed effects. A period dummy is equal to 1 for a given firm if its external finance use is computed as an average over a given period. Our results are not affected (Panel C of Table A.2).

Fourth, we run median regressions which are robust to outliers and allow us to investigate industry-country median external finance use. The results are presented in Panel D of Table A.2 and the standard errors clustered on the industry-country level are bootstrapped. The conditional median effects are economically smaller and statistically insignificant, although in all cases they hold proper sign. ${ }^{15}$

Last, instead of industry value-added growth in the US, we use growth rates of industries in other OECD countries as proxies for unobserved growth opportunities. By doing so, we depart from the assumption that growth opportunities counterfactuals should be based on the growth experience of a country with a relatively frictionless financial system. On the other hand, using realized growth of industries in other countries allows us to check whether our main results aren't driven by the US specific growth shocks. Specifically, for a set of OECD countries, we run regressions equivalent to specifica-

\footnotetext{
${ }^{15}$ Additionally, our results are robust to excluding Bulgaria and the Netherlands, which are countries with the lowest and highest levels of financial development in our sample. These results are available upon request.
} 
tion 1, where financial development is approximated by total capitalization and growth opportunities by industry value-added growth in a given OECD country. The results of this exercise are presented in Table A.4. Although, the set of estimated coefficients on the interaction term is diverse, all but one coefficient that are significant at the 10 percent level are positive. The exception is the negative and significant coefficient obtained using industry growth rates for Slovakia, which can be explained by the very specific development of the manufacturing sector in this transition country. All coefficients that are significant on 10 percent level are plot against the total capitalization of the country used as a growth opportunities benchmark in Figure 1. Financial development of a benchmark country seems to play a limited role in the size of the estimated coefficient of interest.

\subsection{Alternative Measures of Financial Development}

We check our results by investigating the effect of other dimensions of financial development on the allocation of external finance (Table A.5). First, we test the hypothesis that the higher the involvement of government in the banking sector, the lower the efficiency of allocation of finance to growing industries. To the extent that incentives of government as the owner of banks may not be fully in line with profit maximization, the government banks may be more distorted when allocating credit. Thus, we would expect that interaction of the government bank ownership and growth opportunities would be negative in the external finance use equation. We find that this is the case for both the level of government ownership and the level of government control in the top 10 banks in 1995 as calculated by La Porta et al. (2002).

Second, we investigate whether the operational efficiency of the banks and the level of competition in the banking sector increase allocative efficiency. To the extent the competition among banks increases the quality of the financial sector, it may comparatively improve the chance of obtaining credit for firms operating in industries with potential growth prospects. In line with Demirguc-Kunt et al. (2004), we approximate operational 
efficiency and competitiveness of banking sector by the overhead costs and the net interest margin. The former reflects operational cost inefficiencies possibly associated with the market power while the later measures the mark-up between the interest received from borrowers and the interest paid to savers and thus it effectively approximates the degree of competition in traditional operations of the bank. Our findings suggest that higher mark-ups and cost inefficiencies are related to less efficient allocation of external finance.

Lastly, we use an all-encompassing market-based approximation of the countrylevel institutional quality, namely the control premium estimated by Dyck and Zingales (2004). The private control premiums correspond to the benefits enjoyed by the controlling shareholder and not shared by other shareholders. They arise as a consequence of the lack of limits to the extraction of private benefits, and they reflect the inverse of the level of investor protection in the country. Dyck and Zingales (2004) show that the control premiums are higher in countries with less deep financial markets, more concentrated ownership, less protected minority shareholders and weaker law enforcement. Our results are weakly in line with the hypothesis that low quality of institutions is related to lower allocative efficiency.

\section{Conclusion}

In this paper, we study the allocation function of the financial system. Using two alternative proxies for the global industry-specific component of growth opportunities, we show that comparable firms with positive growth opportunities are more likely to obtain external finance in countries with more developed financial markets. Given that our sample consists of relatively large and well-established firms which are shown to be less affected by financial development, ${ }^{16}$ it is likely that the economic significance of our result is even larger in the overall population.

\footnotetext{
${ }^{16}$ See Arellano et al. (2008) for recent evidence.
} 
Our findings complement the existing literature which focuses on the implications of financial development on capital expenditures and growth. However, the most important role of financial system in the link from the growth opportunities through investment to growth is to provide external finance, a test of which is a primary question of our paper. In light of the outlined mechanism, we plan to complement our analysis by a second step in which we check whether the improved capital allocation function of more developed financial markets leads to higher corporate investment and growth precisely through more extensive use of external finance. 


\section{References}

Abiad, A., Oomes, N., Ueda, K., October 2008. The quality effect: Does financial liberalization improve the allocation of capital? Journal of Development Economics 87 (2), $270-282$.

Arellano, C., Bai, Y., Zhang, J., 2008. Firm Dynamics and Financial Development (Working Paper).

Baker, M., Stein, J., Wurgler, J., 2003. When Does the Market Matter? Stock Prices and the Investment of Equity-Dependent Firms. Quarterly Journal of Economics 118 (3), 969-1005.

Beck, T., Demirgüç-Kunt, A., Levine, R., 2000. A New Database on Financial Development and Structure. World Bank Economic Review 14, 597-605.

Bekaert, G., Harvey, C., Lundblad, C., Siegel, S., 2007. Global growth opportunities and market integration. The Journal of Finance 62 (3), 1081-1137.

Bena, J., Jurajda, S., 2007. Which firms benefit more from financial development? CERGE-EI Working Papers wp330, The Center for Economic Research and Graduate Education - Economic Institute, Prague.

Boyd, J. H., Prescott, E. C., April 1986. Financial intermediary-coalitions. Journal of Economic Theory 38 (2), 211-232.

Ciccone, A., Papaioannou, E., 2006. Adjustment to target capital, finance and growth. CEPR Discussion Papers 5969.

Cook, J., Stefanski, L., 1994. Simulation-extrapolation estimation in parametric measurement error models. Journal of the American Statistical Association 89 (428), $1314-1328$. 
Demirguc-Kunt, A., Laeven, L., Levine, R., June 2004. Regulations, market structure, institutions, and the cost of financial intermediation. Journal of Money, Credit and Banking 36 (3), 593-622.

Doms, M. E., Dunne, T., April 1998. Capital adjustment patterns in manufacturing plants. Review of Economic Dynamics 1 (2), 409-429.

Dyck, A., Zingales, L., 2004. Private benefits of control: An international comparison. Journal of Finance 59 (2), 537-600.

Fisman, R., Love, I., 2004. Financial development and growth in the short and long run. NBER Working Papers 10236, National Bureau of Economic Research, Inc.

Fisman, R., Love, I., 2007. Financial Dependence and Growth Revisited. Journal of the European Economic Association 5 (2-3), 470-479.

Galindo, A., Schiantarelli, F., Weiss, A., July 2007. Does financial liberalization improve the allocation of investment?: Micro-evidence from developing countries. Journal of Development Economics 83 (2), 562-587.

Ilyina, A., Samaniego, R. M., 2008. Technology and finance. IMF Working Papers 08/182, International Monetary Fund.

Islam, S. S., Mozumdar, A., March 2007. Financial market development and the importance of internal cash: Evidence from international data. Journal of Banking \& Finance 31 (3), 641-658.

Klapper, L., Laeven, L., Rajan, R., December 2006. Entry regulation as a barrier to entrepreneurship. Journal of Financial Economics 82 (3), 591-629.

La Porta, R., Lopez-De-Silanes, F., Shleifer, A., 2002. Government Ownership of Banks. The Journal of Finance 57 (1), 265-301. 
Levine, R., 2005. Finance and growth: Theory and evidence. In: Aghion, P., Durlauf, S. (Eds.), Handbook of Economic Growth. Vol. 1. Ch. 12, pp. 865-934.

Love, I., 2003. Financial development and financing constraints: International evidence from the structural investment model. Review of Financial Studies 16 (3), 765-791.

Nilsen, Ø. A., Schiantarelli, F., December 2003. Zeros and lumps in investment: Empirical evidence on irreversibilities and nonconvexities. The Review of Economics and Statistics 85 (4), 1021-1037.

Rajan, R., Zingales, L., 1998. Financial Dependence and Growth. The American Economic Review 88 (3), 559-586.

Townsend, R. M., October 1979. Optimal contracts and competitive markets with costly state verification. Journal of Economic Theory 21 (2), 265-293.

Wurgler, J., 2000. Financial markets and the allocation of capital. Journal of Financial Economics 58 (1), 187-214. 
Table 1: External Finance Use: Firm Data by Country, 1996-2005

\begin{tabular}{|c|c|c|c|c|c|c|}
\hline \multirow[b]{2}{*}{ Country } & \multirow[b]{2}{*}{$\mathrm{N}$} & \multirow[b]{2}{*}{ Mean } & \multirow[b]{2}{*}{ S.D. } & \multicolumn{3}{|c|}{ Percentile } \\
\hline & & & & 25 th & 50 th & 75 th \\
\hline Austria & 143 & -0.017 & 0.063 & -0.058 & -0.002 & 0.023 \\
\hline Belgium & 1,745 & 0.001 & 0.037 & -0.012 & 0.000 & 0.016 \\
\hline Bulgaria & 171 & 0.021 & 0.051 & -0.001 & 0.010 & 0.047 \\
\hline Czech Republic & 1,091 & -0.007 & 0.046 & -0.027 & -0.005 & 0.014 \\
\hline Estonia & 139 & 0.007 & 0.045 & -0.014 & 0.002 & 0.031 \\
\hline Finland & 744 & -0.007 & 0.037 & -0.023 & -0.004 & 0.012 \\
\hline France & 4,882 & 0.002 & 0.032 & -0.008 & 0.003 & 0.016 \\
\hline Germany & 685 & -0.004 & 0.057 & -0.027 & 0.006 & 0.030 \\
\hline Greece & 743 & 0.026 & 0.034 & 0.007 & 0.025 & 0.044 \\
\hline Hungary & 105 & -0.011 & 0.050 & -0.038 & -0.012 & 0.019 \\
\hline Ireland & 174 & 0.003 & 0.043 & -0.007 & 0.000 & 0.014 \\
\hline Italy & 5,233 & 0.009 & 0.029 & -0.004 & 0.008 & 0.023 \\
\hline Latvia & 181 & 0.024 & 0.053 & -0.002 & 0.017 & 0.053 \\
\hline Lithuania & 57 & 0.053 & 0.053 & 0.026 & 0.054 & 0.085 \\
\hline Netherlands & 430 & -0.006 & 0.041 & -0.019 & -0.003 & 0.006 \\
\hline Poland & 1,445 & 0.000 & 0.051 & -0.023 & -0.001 & 0.022 \\
\hline Portugal & 531 & 0.008 & 0.039 & -0.009 & 0.006 & 0.028 \\
\hline Slovakia & 106 & -0.019 & 0.043 & -0.044 & -0.018 & 0.001 \\
\hline Spain & 3,141 & 0.007 & 0.033 & -0.005 & 0.003 & 0.020 \\
\hline Sweden & 1,421 & -0.005 & 0.041 & -0.023 & -0.003 & 0.013 \\
\hline UK & 3,498 & 0.006 & 0.038 & -0.006 & 0.003 & 0.018 \\
\hline Total & 26,665 & 0.004 & 0.038 & -0.009 & 0.003 & 0.020 \\
\hline
\end{tabular}

Note: The number of observations in the sample, $\mathrm{N}$, corresponds to the number of firms with non-missing average External Finance Use (EFU) calculated based on at least 5 annual EFU values within the 1996-2005 period. Annual EFU is defined as change in shareholders' capital plus change in firm's long-term debt plus change in firm's other non-current liabilities scaled by total assets. Before computing the statistics we remove EFU outliers (we use the 1-to-99 percentile range of annual EFU values). See Appendix Tables A.1a, A.1b, and A.1c for complete definitions and sources of variables. 
Table 2: Financial Development: European Countries

\begin{tabular}{lcccclll}
\hline & Mean & S.D. & Min & Max & Min Country & Max Country & N \\
\hline Total Capitalization & 1.05 & 0.94 & 0.08 & 4.21 & Latvia & Netherlands & 20 \\
Private Credit & 0.70 & 0.68 & 0.06 & 3.31 & Latvia & Netherlands & 21 \\
Market Capitalization & 0.32 & 0.34 & 0.00 & 1.33 & Bulgaria & UK & 20 \\
Market Value Traded & 0.19 & 0.21 & 0.00 & 0.82 & Bulgaria & Netherlands & 20 \\
Accounting Standards & 0.64 & 0.13 & 0.36 & 0.83 & Portugal & Sweden & 12 \\
Gov. Bank Ownership & 0.37 & 0.28 & 0.00 & 0.86 & UK & Bulgaria & 18 \\
Gov. Bank Control & 0.38 & 0.31 & 0.00 & 0.92 & UK & Bulgaria & 18 \\
Overhead Costs & 3.69 & 2.19 & 0.25 & 9.45 & Ireland & Bulgaria & 19 \\
Net Interest Margin & 3.65 & 1.92 & 1.18 & 7.28 & Netherlands & Latvia & 19 \\
Control Premium & 0.17 & 0.19 & 0.01 & 0.58 & Netherlands & Czech Republic & 11 \\
\hline
\end{tabular}

Note: We present the Min, Max, Mean, and Standard Deviation of country-level financial development measures across Europe. Accounting Standards are as of 1990, Control Premium is estimated for the 1990-2000 period, Government Bank Ownership and Government Bank Control are as of 1995, and all remaining measures are as of 1996. Total Capitalization, Market Capitalization, and Market Value Traded are missing for Estonia. Accounting Standards are missing for Bulgaria, Czech Republic, Estonia, Hungary, Ireland, Lithuania, Latvia, Poland, and Slovakia. Government Bank Ownership and Government Bank Control are missing for Estonia, Lithuania, and Latvia. Overhead Costs and Net Interest Margin are missing for Finland and Sweden. Control Premium is missing for Belgium, Bulgaria, Estonia, Greece, Hungary, Ireland, Lithuania, Latvia, Poland, and Slovakia. See Appendix Tables A.1a, A.1b, and A.1c for complete definitions and sources of variables. 


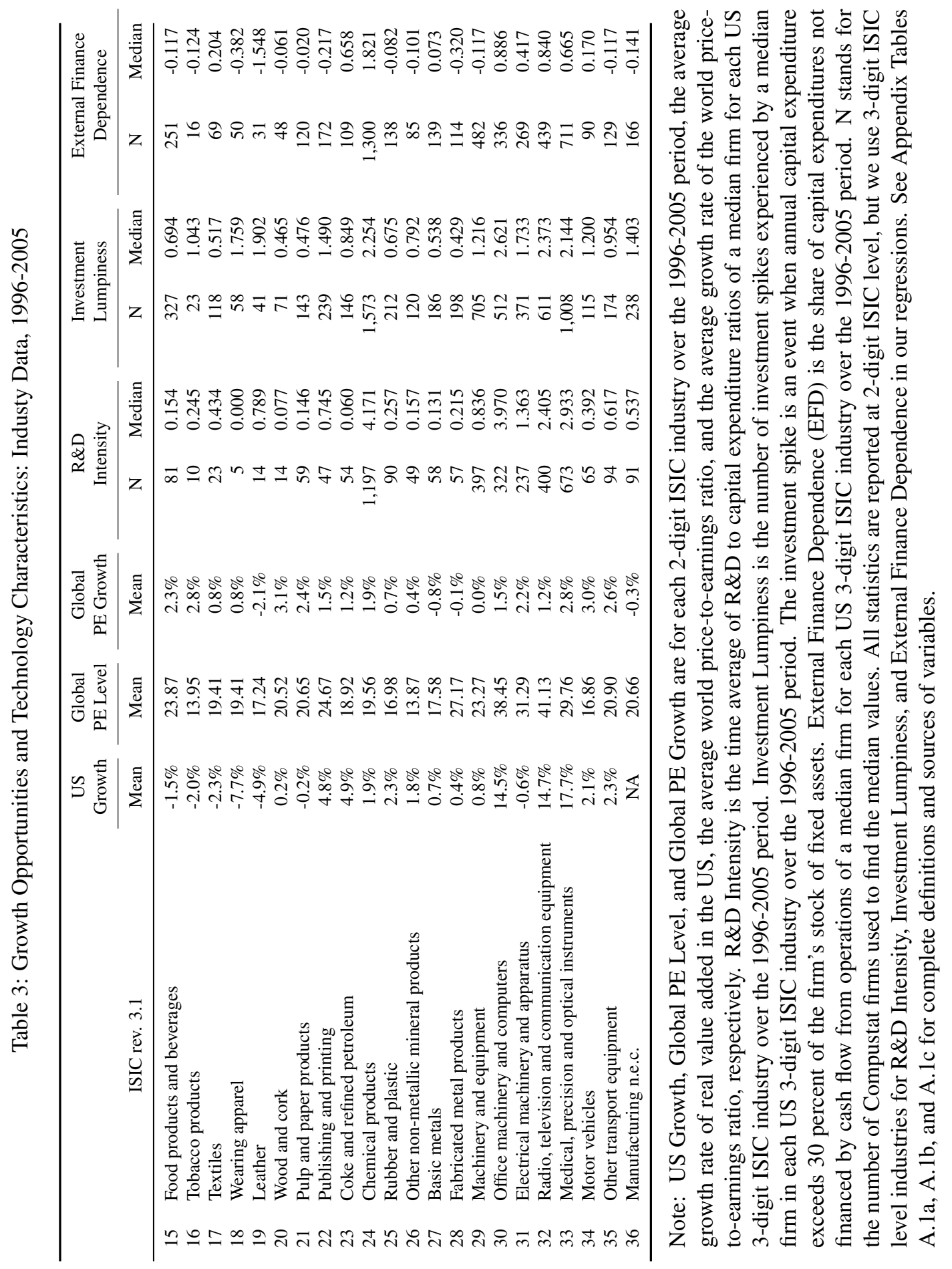


Table 4: Growth Opportunities and Technology Characteristics: Descriptive Statistics

\begin{tabular}{|c|c|c|c|c|c|c|}
\hline & \multicolumn{6}{|c|}{ Panel A: Basic Statistics } \\
\hline & US & Global & Global & R\&D & Investment & \\
\hline & Growth & PE Level & PE Growth & Intensity & Lumpiness & EFD \\
\hline Mean & $2.4 \%$ & 22.55 & $1.3 \%$ & 0.928 & 1.226 & 0.051 \\
\hline S.D. & $6.3 \%$ & 7.16 & $1.4 \%$ & 1.478 & 0.723 & 0.885 \\
\hline \multirow[t]{4}{*}{$\mathrm{N}$} & 21 & 22 & 22 & 58 & 58 & 58 \\
\hline & \multicolumn{6}{|c|}{ Panel B: Rank Correlations } \\
\hline & US & Global & Global & R\&D & Investment & \\
\hline & Growth & PE Level & PE Growth & Intensity & Lumpiness & EFD \\
\hline US Growth & 1 & & & & & \\
\hline \multirow[t]{2}{*}{ Global PE Level } & $\begin{array}{c}0.335 \\
(0.138)\end{array}$ & 1 & & & & \\
\hline & 21 & & & & & \\
\hline \multirow[t]{3}{*}{ Global PE Growth } & 0.165 & 0.153 & 1 & & & \\
\hline & $(0.475)$ & $(0.509)$ & & & & \\
\hline & 21 & 21 & & & & \\
\hline \multirow[t]{3}{*}{ R\&D Intensity } & 0.416 & 0.480 & 0.060 & 1 & & \\
\hline & $(0.061 *)$ & $(0.028 * *)$ & $(0.795)$ & & & \\
\hline & 21 & 21 & 21 & & & \\
\hline Investment & 0.342 & 0.327 & 0.059 & 0.653 & 1 & \\
\hline \multirow[t]{2}{*}{ Lumpiness } & $(0.130)$ & $(0.147)$ & $(0.801)$ & $(0.000 * * *)$ & & \\
\hline & 21 & 21 & 21 & 58 & & \\
\hline \multirow[t]{3}{*}{ EFD } & 0.552 & 0.281 & 0.293 & 0.216 & 0.255 & 1 \\
\hline & $(0.010 * * *)$ & $(0.217)$ & (0.198) & (0.104) & $(0.054 *)$ & \\
\hline & 21 & 21 & 21 & 58 & 58 & \\
\hline
\end{tabular}

Note: In Panel A, we present descriptive statistics for US Growth, Global PE Level, and Global PE Growth on 2-digit ISIC industries and R\&D Intensity, Investment Lumpiness and EFD on 3-digit ISIC industries over the 1996-2005 period (see Tables 3 and A.1b for definitions of the variables). Panel B presents Spearman rank correlations with corresponding p-values in brackets and the number of observations used to estimate it. 
Table 5: Financial Development and External Finance Use: Basic Estimates

\begin{tabular}{|c|c|c|c|c|c|}
\hline & $\begin{array}{c}\text { Total } \\
\text { Capitalization }\end{array}$ & $\begin{array}{l}\text { Private } \\
\text { Credit }\end{array}$ & $\begin{array}{c}\text { Market } \\
\text { Capitalization }\end{array}$ & $\begin{array}{c}\text { Market } \\
\text { Value Traded }\end{array}$ & $\begin{array}{c}\text { Accounting } \\
\text { Standards }\end{array}$ \\
\hline FD * US Growth & $\begin{array}{l}0.027 * * * \\
(0.01)\end{array}$ & $\begin{array}{l}0.053 * * * \\
(0.016)\end{array}$ & $\begin{array}{l}0.038 * \\
(0.02)\end{array}$ & $\begin{array}{l}0.115 * * * \\
(0.04)\end{array}$ & $\begin{array}{l}0.084 \\
(0.054)\end{array}$ \\
\hline Total Assets & $\begin{array}{l}-0.062 * * * \\
(0.01)\end{array}$ & $\begin{array}{l}-0.062 * * * \\
(0.01)\end{array}$ & $\begin{array}{l}-0.062 * * * \\
(0.01)\end{array}$ & $\begin{array}{l}-0.062 * * * \\
(0.01)\end{array}$ & $\begin{array}{l}-0.069 * * * \\
(0.01)\end{array}$ \\
\hline Total Assets Squared & $\begin{array}{l}0.064 * * * \\
(0.011)\end{array}$ & $\begin{array}{l}0.064 * * * \\
(0.011)\end{array}$ & $\begin{array}{l}0.064 * * * \\
(0.011)\end{array}$ & $\begin{array}{l}0.064 * * * \\
(0.011)\end{array}$ & $\begin{array}{l}0.067 * * * \\
(0.011)\end{array}$ \\
\hline Employees & $\begin{array}{l}-0.062 * * * \\
(0.019)\end{array}$ & $\begin{array}{l}-0.063 * * * \\
(0.019)\end{array}$ & $\begin{array}{l}-0.061 * * * \\
(0.019)\end{array}$ & $\begin{array}{l}-0.062 * * * \\
(0.019)\end{array}$ & $\begin{array}{l}-0.037 * \\
(0.02)\end{array}$ \\
\hline Employees Squared & $\begin{array}{l}0.187 * * * \\
(0.053)\end{array}$ & $\begin{array}{l}0.189 * * * \\
(0.053)\end{array}$ & $\begin{array}{l}0.185 * * * \\
(0.053)\end{array}$ & $\begin{array}{l}0.186 * * * \\
(0.053)\end{array}$ & $\begin{array}{l}0.161 * * * \\
(0.057)\end{array}$ \\
\hline Age & $\begin{array}{l}-0.010^{* * * *} \\
(0.003)\end{array}$ & $\begin{array}{l}-0.010 * * * \\
(0.003)\end{array}$ & $\begin{array}{l}-0.010 * * * \\
(0.003)\end{array}$ & $\begin{array}{l}-0.010 * * * \\
(0.003)\end{array}$ & $\begin{array}{l}-0.007 * * \\
(0.003)\end{array}$ \\
\hline Age Squared & $\begin{array}{l}0.007 * \\
(0.004)\end{array}$ & $\begin{array}{l}0.007 * \\
(0.004)\end{array}$ & $\begin{array}{l}0.007 * \\
(0.004)\end{array}$ & $\begin{array}{l}0.007 * \\
(0.004)\end{array}$ & $\begin{array}{l}0.005 \\
(0.004)\end{array}$ \\
\hline Leverage & $\begin{array}{l}-0.019 * * * \\
(0.002)\end{array}$ & $\begin{array}{l}-0.019 * * * \\
(0.002)\end{array}$ & $\begin{array}{l}-0.019 * * * \\
(0.002)\end{array}$ & $\begin{array}{l}-0.019 * * * \\
(0.002)\end{array}$ & $\begin{array}{l}-0.019 * * * \\
(0.002)\end{array}$ \\
\hline Tangibility & $\begin{array}{l}-0.014 * * * \\
(0.002)\end{array}$ & $\begin{array}{l}-0.014 * * * \\
(0.002)\end{array}$ & $\begin{array}{l}-0.014 * * * \\
(0.002)\end{array}$ & $\begin{array}{l}-0.014 * * * \\
(0.002)\end{array}$ & $\begin{array}{l}-0.013 * * * \\
(0.002)\end{array}$ \\
\hline Collateral & $\begin{array}{l}0.002 \\
(0.002)\end{array}$ & $\begin{array}{l}0.002 \\
(0.002)\end{array}$ & $\begin{array}{l}0.002 \\
(0.002)\end{array}$ & $\begin{array}{l}0.002 \\
(0.002)\end{array}$ & $\begin{array}{l}0.001 \\
(0.002)\end{array}$ \\
\hline Cash & $\begin{array}{l}-0.004 \\
(0.003)\end{array}$ & $\begin{array}{l}-0.004 \\
(0.003)\end{array}$ & $\begin{array}{l}-0.004 \\
(0.003)\end{array}$ & $\begin{array}{l}-0.004 \\
(0.003)\end{array}$ & $\begin{array}{l}-0.006 * * \\
(0.003)\end{array}$ \\
\hline Quoted & $\begin{array}{l}0.013 * * * \\
(0.001)\end{array}$ & $\begin{array}{l}0.013 * * * \\
(0.001)\end{array}$ & $\begin{array}{l}0.013 * * * \\
(0.001)\end{array}$ & $\begin{array}{l}0.013 * * * \\
(0.001)\end{array}$ & $\begin{array}{l}0.016 * * * \\
(0.002)\end{array}$ \\
\hline Constant & $\begin{array}{l}-0.006 \\
(0.006)\end{array}$ & $\begin{array}{l}-0.006 \\
(0.006)\end{array}$ & $\begin{array}{l}-0.006 \\
(0.006)\end{array}$ & $\begin{array}{l}-0.006 \\
(0.007)\end{array}$ & $\begin{array}{l}-0.009 \\
(0.006)\end{array}$ \\
\hline $\begin{array}{l}\text { Country and Industry } \\
\text { Fixed Effects }\end{array}$ & Yes & Yes & Yes & Yes & Yes \\
\hline $\mathrm{R}^{2}$ & 0.078 & 0.077 & 0.077 & 0.078 & 0.076 \\
\hline $\mathrm{N}$ & 25,419 & 25,544 & 25,419 & 25,419 & 22,239 \\
\hline
\end{tabular}

Note: The dependent variable is the time average of annual firm-level External Finance Use (EFU) defined as change in shareholders' capital plus change in a firm's long-term debt plus change in a firm's other noncurrent liabilities scaled by total assets. The average is taken over years in which a firm is present in the sample within the 1996-2005 period. US Growth is the time average of the real value-added growth of US 2-digit ISIC industries calculated, for each firm, over the same years for which EFU is computed. Country-level measures of Financial Development (FD) are predetermined. Firm-level control variables come from the first year a firm enters the sample and remain fixed over time. Total Assets are in EUR billions. Employees is the number of employees and it is scaled down by 10,000. Age is the number of years since a firm's incorporation and it is scaled down by 100. Leverage is the ratio of long- plus short-term debt to total assets. Tangibility is the ratio of fixed assets to total assets. Collateral is measured as fixed assets plus inventories plus receivables divided by total assets. Cash is the ratio of cash holdings to total assets. Quoted is a dummy variable with a base of non-quoted firms. See Appendix Tables A.1a, A.1b, and A.1c for complete definitions and sources of variables. All specifications are linear regressions with outliers removed (we use the 1-to-99 percentile range of the dependent variable). We always control for country and 3-digit ISIC industry dummies. Robust standard errors (clustered at industry-country level) are reported in parentheses; $*, * *$, and $* * *$ denote significance at the $10 \%, 5 \%$, and $1 \%$ level, respectively. 
Table 6: Financial Development and External Finance Use: Growth Opportunities

\begin{tabular}{|c|c|c|c|c|c|}
\hline & $\begin{array}{c}\text { Total } \\
\text { Capitalization }\end{array}$ & $\begin{array}{l}\text { Private } \\
\text { Credit }\end{array}$ & $\begin{array}{c}\text { Market } \\
\text { Capitalization }\end{array}$ & $\begin{array}{c}\text { Market } \\
\text { Value Traded }\end{array}$ & $\begin{array}{l}\text { Accounting } \\
\text { Standards }\end{array}$ \\
\hline & \multicolumn{5}{|c|}{ Panel A: All Europe } \\
\hline FD * US Growth & $\begin{array}{l}0.027 * * * \\
(0.01)\end{array}$ & $\begin{array}{l}0.053 * * * \\
(0.016)\end{array}$ & $\begin{array}{l}0.038^{*} \\
(0.02)\end{array}$ & $\begin{array}{l}0.115^{* * *} \\
(0.04)\end{array}$ & $\begin{array}{l}0.084 \\
(0.054)\end{array}$ \\
\hline $\mathrm{R}^{2}$ & 0.078 & 0.077 & 0.077 & 0.078 & 0.076 \\
\hline $\mathrm{N}$ & 25,419 & 25,544 & 25,419 & 25,419 & 22,239 \\
\hline \multirow[t]{2}{*}{ FD * Global PE Level } & 0.003 & 0.004 & 0.004 & 0.004 & $0.021 *$ \\
\hline & $(0.002)$ & $(0.003)$ & $(0.003)$ & $(0.008)$ & $(0.011)$ \\
\hline $\mathrm{R}^{2}$ & 0.077 & 0.076 & 0.077 & 0.077 & 0.075 \\
\hline $\mathrm{N}$ & 26,526 & 26,665 & 26,526 & 26,526 & 23,196 \\
\hline \multirow[t]{2}{*}{ FD * Global PE Growth } & $0.026 * * *$ & $0.034 * * *$ & $0.070 * * *$ & $0.088 * *$ & $0.043 * *$ \\
\hline & $(0.008)$ & $(0.013)$ & $(0.018)$ & $(0.039)$ & $(0.019)$ \\
\hline $\mathrm{R}^{2}$ & 0.078 & 0.077 & 0.078 & 0.077 & 0.076 \\
\hline \multirow[t]{2}{*}{$\mathrm{N}$} & 26,526 & 26,665 & 26,526 & 26,526 & 23,196 \\
\hline & \multicolumn{5}{|c|}{ Panel B: EU-15 } \\
\hline FD * US Growth & $\begin{array}{l}0.036 * * * \\
(0.01)\end{array}$ & $\begin{array}{l}0.069 * * * \\
(0.015)\end{array}$ & $\begin{array}{l}0.046^{* *} \\
(0.02)\end{array}$ & $\begin{array}{l}0.139 * * * \\
(0.038)\end{array}$ & $\begin{array}{l}0.084 \\
(0.054)\end{array}$ \\
\hline $\mathrm{R}^{2}$ & 0.077 & 0.077 & 0.076 & 0.077 & 0.076 \\
\hline $\mathrm{N}$ & 22,407 & 22,407 & 22,407 & 22,407 & 22,239 \\
\hline FD * Global PE Level & 0.003 & 0.005 & 0.004 & 0.005 & $0.021 *$ \\
\hline & $(0.002)$ & $(0.004)$ & $(0.003)$ & $(0.008)$ & $(0.011)$ \\
\hline $\mathrm{R}^{2}$ & 0.077 & 0.075 & 0.075 & 0.075 & 0.075 \\
\hline $\mathrm{N}$ & 26,526 & 23,370 & 23,370 & 23,370 & 23,196 \\
\hline FD * Global PE Growth & $0.030 * * *$ & $0.041 * * *$ & $0.075 * * *$ & $0.100 * * *$ & $0.043 * *$ \\
\hline & $(0.008)$ & $(0.013)$ & $(0.018)$ & $(0.038)$ & $(0.019)$ \\
\hline $\mathrm{R}^{2}$ & 0.076 & 0.076 & 0.076 & 0.076 & 0.076 \\
\hline $\mathrm{N}$ & 23,370 & 23,370 & 23,370 & 23,370 & 23,196 \\
\hline
\end{tabular}

Note: The dependent variable is the time average of annual firm-level External Finance Use (EFU) defined as change in shareholders' capital plus change in a firm's long-term debt plus change in a firm's other noncurrent liabilities scaled by total assets. The average is taken over years in which a firm is present in the sample within the 1996-2005 period. US Growth is the time average of the real value-added growth of US 2-digit ISIC industries calculated, for each firm, over the same years for which EFU is computed. Global PE Level and Global PE Growth are the time averages of the world price-to-earnings ratios and of the growth rates of the world price-to-earnings ratios at 2-digit ISIC level, respectively. The time span of values that enter Global PE Level and Global PE Growth calculations is determined analogously to US Growth. Panel A is based on full sample of European countries. Panel B is based on EU-15 countries. All specifications are linear regressions with outliers removed (observations outside the 1-to-99 percentile range of the dependent variable), include a constant, firm-level controls (see Table 5 notes for their definitions), and 3-digit ISIC industry and country dummies. *,**, and *** denote significance at the $10 \%, 5 \%$, and $1 \%$ level, respectively, based on robust standard errors clustered at the industry-country level. 
Table 7: Financial Development and External Finance Use: Technology Characteristics

\begin{tabular}{|c|c|c|c|c|c|}
\hline & $\begin{array}{c}\text { Total } \\
\text { Capitalization }\end{array}$ & $\begin{array}{l}\text { Private } \\
\text { Credit }\end{array}$ & $\begin{array}{c}\text { Market } \\
\text { Capitalization }\end{array}$ & $\begin{array}{c}\text { Market } \\
\text { Value Traded }\end{array}$ & $\begin{array}{c}\text { Accounting } \\
\text { Standards }\end{array}$ \\
\hline & \multicolumn{5}{|c|}{ Panel A: All Europe } \\
\hline $\mathrm{FD} * \mathrm{R} \& \mathrm{D}$ Intensity & $\begin{array}{l}0.080 * * * \\
(0.028)\end{array}$ & $\begin{array}{l}0.147 * * \\
(0.06)\end{array}$ & $\begin{array}{l}0.098^{*} \\
(0.058)\end{array}$ & $\begin{array}{l}0.269 * * \\
(0.12)\end{array}$ & $\begin{array}{l}0.111 \\
(0.269)\end{array}$ \\
\hline $\mathrm{R}^{2}$ & 0.077 & 0.075 & 0.075 & 0.075 & 0.073 \\
\hline $\mathrm{N}$ & 26,259 & 24,629 & 24,517 & 24,517 & 21,495 \\
\hline FD * Investment & $0.247 * * *$ & $0.473 * * *$ & $0.309 * * *$ & $0.760 * * *$ & 0.43 \\
\hline \multirow[t]{3}{*}{ Lumpiness } & $(0.058)$ & $(0.134)$ & $(0.11)$ & $(0.236)$ & $(0.504)$ \\
\hline & 0.078 & 0.077 & 0.077 & 0.077 & 0.075 \\
\hline & 26,514 & 26,653 & 26,514 & 26,514 & 23,187 \\
\hline \multirow[t]{2}{*}{$\mathrm{FD} * \mathrm{EFD}$} & $0.091 * *$ & $0.158 * *$ & 0.136 & $0.305^{*}$ & 0.502 \\
\hline & $(0.04)$ & $(0.074)$ & $(0.083)$ & $(0.183)$ & $(0.437)$ \\
\hline $\mathrm{R}^{2}$ & 0.077 & 0.076 & 0.076 & 0.076 & 0.075 \\
\hline \multirow[t]{2}{*}{$\mathrm{N}$} & 26,259 & 26,392 & 26,259 & 26,259 & 22,975 \\
\hline & \multicolumn{5}{|c|}{ Panel B: EU-15 } \\
\hline FD * R\&D Intensity & $\begin{array}{l}0.079 * * * \\
(0.029)\end{array}$ & $\begin{array}{l}0.141 * * \\
(0.06)\end{array}$ & $\begin{array}{l}0.090 \\
(0.057)\end{array}$ & $\begin{array}{l}0.257 * * \\
(0.126)\end{array}$ & $\begin{array}{l}0.111 \\
(0.269)\end{array}$ \\
\hline $\mathrm{R}^{2}$ & 0.074 & 0.074 & 0.074 & 0.074 & 0.073 \\
\hline $\mathrm{N}$ & 21,655 & 21,655 & 21,655 & 21,655 & 21,495 \\
\hline FD * Investment & $0.207 * * *$ & $0.401 * * *$ & $0.235^{* *}$ & $0.596 * *$ & 0.430 \\
\hline Lumpiness & $(0.054)$ & $(0.12)$ & $(0.105)$ & $(0.24)$ & $(0.504)$ \\
\hline $\mathrm{R}^{2}$ & 0.076 & 0.076 & 0.075 & 0.075 & 0.075 \\
\hline $\mathrm{N}$ & 23,361 & 23,361 & 23,361 & 23,361 & 23,187 \\
\hline $\mathrm{FD} * \mathrm{EFD}$ & $\begin{array}{l}0.120 * * * \\
(0.045)\end{array}$ & $\begin{array}{l}0.189 * * \\
(0.09)\end{array}$ & $\begin{array}{l}0.178 * \\
(0.093)\end{array}$ & $\begin{array}{l}0.395 * * \\
(0.194)\end{array}$ & $\begin{array}{l}0.502 \\
(0.437)\end{array}$ \\
\hline $\mathrm{R}^{2}$ & 0.075 & 0.075 & 0.075 & 0.075 & 0.075 \\
\hline $\mathrm{N}$ & 23,149 & 23,149 & 23,149 & 23,149 & 22,975 \\
\hline
\end{tabular}

Note: The dependent variable is the time average of annual firm-level External Finance Use (EFU) defined as change in shareholders' capital plus change in a firm's long-term debt plus change in a firm's other non-current liabilities scaled by total assets. The average is taken over years in which a firm is present in the sample within the 1996-2005 period. R\&D Intensity is the time average of R\&D to capital expenditure ratios of a median firm for each US 3-digit ISIC industry over the 1996-2005 period. Investment Lumpiness is the number of investment spikes experienced by a median firm in each US 3-digit ISIC industry over the 1996-2005 period. The investment spike is an event when annual capital expenditure exceeds 30 percent of the firm's stock of fixed assets. External Finance Dependence (EFD) is the share of capital expenditures not financed by cash flow from operations of a median firm for each US 3-digit ISIC industry over the 1996-2005 period. Panel A is based on full sample of European countries. Panel B is based on EU-15 countries. All specifications are linear regressions with outliers removed (observations outside the 1-to-99 percentile range of the dependent variable), include a constant, firm-level controls (see Table 5 notes for their definitions), and 3-digit ISIC industry and country dummies. *, **, and *** denote significance at the $10 \%, 5 \%$, and $1 \%$ level, respectively, based on robust standard errors clustered at the industry-country level. 
Table 8: Financial Development and External Finance Use: Growth vs. Technology

\begin{tabular}{|c|c|c|c|c|c|}
\hline & $\begin{array}{c}\text { Total } \\
\text { Capitalization }\end{array}$ & $\begin{array}{l}\text { Private } \\
\text { Credit }\end{array}$ & $\begin{array}{c}\text { Market } \\
\text { Capitalization }\end{array}$ & $\begin{array}{c}\text { Market } \\
\text { Value Traded }\end{array}$ & $\begin{array}{c}\text { Accounting } \\
\text { Standards }\end{array}$ \\
\hline & \multicolumn{5}{|c|}{ Panel A: US Growth } \\
\hline FD * US Growth & $\begin{array}{l}0.026 * * \\
(0.011)\end{array}$ & $\begin{array}{l}0.050 * * * \\
(0.018)\end{array}$ & $\begin{array}{l}0.035 \\
(0.023)\end{array}$ & $\begin{array}{l}0.111 * * \\
(0.045)\end{array}$ & $\begin{array}{l}0.087 \\
(0.06)\end{array}$ \\
\hline $\mathrm{FD} * \mathrm{R} \& \mathrm{D}$ Intensity & $\begin{array}{l}0.048 * \\
(0.025)\end{array}$ & $\begin{array}{l}0.095^{*} \\
(0.049)\end{array}$ & $\begin{array}{l}0.05 \\
(0.051)\end{array}$ & $\begin{array}{l}0.127 \\
(0.124)\end{array}$ & $\begin{array}{l}-0.007 \\
(0.274)\end{array}$ \\
\hline $\begin{array}{l}\mathrm{R}^{2} \\
\mathrm{~N}\end{array}$ & $\begin{array}{l}0.076 \\
23,410\end{array}$ & $\begin{array}{l}0.075 \\
23,508\end{array}$ & $\begin{array}{l}0.075 \\
23,410\end{array}$ & $\begin{array}{l}0.076 \\
23,410\end{array}$ & $\begin{array}{l}0.074 \\
20,538\end{array}$ \\
\hline FD * US Growth & $\begin{array}{l}0.013 \\
(0.011)\end{array}$ & $\begin{array}{l}0.028 \\
(0.018)\end{array}$ & $\begin{array}{l}0.019 \\
(0.021)\end{array}$ & $\begin{array}{l}0.074 * \\
(0.043)\end{array}$ & $\begin{array}{l}0.078 \\
(0.055)\end{array}$ \\
\hline $\begin{array}{l}\text { FD } * \text { Investment } \\
\text { Lumpiness }\end{array}$ & $\begin{array}{l}0.218 * * * \\
(0.061)\end{array}$ & $\begin{array}{l}0.410 * * * \\
(0.139)\end{array}$ & $\begin{array}{l}0.272 * * \\
(0.112)\end{array}$ & $\begin{array}{l}0.599 * * \\
(0.251)\end{array}$ & $\begin{array}{l}0.296 \\
(0.509)\end{array}$ \\
\hline $\begin{array}{l}\mathrm{R}^{2} \\
\mathrm{~N}\end{array}$ & $\begin{array}{l}0.078 \\
25,407\end{array}$ & $\begin{array}{l}0.078 \\
25,532\end{array}$ & $\begin{array}{l}0.078 \\
25,407\end{array}$ & $\begin{array}{l}0.078 \\
25,407\end{array}$ & $\begin{array}{l}0.076 \\
22,230\end{array}$ \\
\hline FD $*$ US Growth & $\begin{array}{l}0.024 * * \\
(0.011)\end{array}$ & $\begin{array}{l}0.047 * * * \\
(0.017)\end{array}$ & $\begin{array}{l}0.033 \\
(0.021)\end{array}$ & $\begin{array}{l}0.104 * * \\
(0.042)\end{array}$ & $\begin{array}{l}0.076 \\
(0.055)\end{array}$ \\
\hline $\mathrm{FD} * \mathrm{EFD}$ & $\begin{array}{l}0.056 \\
(0.038)\end{array}$ & $\begin{array}{l}0.094 \\
(0.064)\end{array}$ & $\begin{array}{l}0.092 \\
(0.08)\end{array}$ & $\begin{array}{l}0.158 \\
(0.192)\end{array}$ & $\begin{array}{l}0.388 \\
(0.436)\end{array}$ \\
\hline \multirow[t]{2}{*}{$\mathrm{N}$} & $\begin{array}{l}0.077 \\
25,152\end{array}$ & $\begin{array}{l}0.077 \\
25,271\end{array}$ & $\begin{array}{l}0.077 \\
25,152\end{array}$ & $\begin{array}{l}0.077 \\
25,152\end{array}$ & $\begin{array}{l}0.076 \\
22,018\end{array}$ \\
\hline & \multicolumn{5}{|c|}{ Panel B: Global PE Growth } \\
\hline FD * Global PE Growth & $\begin{array}{l}0.027 * * * \\
(0.008)\end{array}$ & $\begin{array}{l}0.035^{* *} \\
(0.014)\end{array}$ & $\begin{array}{l}0.076^{* * *} \\
(0.019)\end{array}$ & $\begin{array}{l}0.098 * * \\
(0.041)\end{array}$ & $\begin{array}{l}0.047 * * \\
(0.021)\end{array}$ \\
\hline FD * R\&D Intensity & $\begin{array}{l}0.063 * * \\
(0.028)\end{array}$ & $\begin{array}{l}0.127 * * \\
(0.059)\end{array}$ & $\begin{array}{l}0.048 \\
(0.055)\end{array}$ & $\begin{array}{l}0.205^{*} \\
(0.122)\end{array}$ & $\begin{array}{l}0.079 \\
(0.27)\end{array}$ \\
\hline $\begin{array}{l}\mathrm{R}^{2} \\
\mathrm{~N}\end{array}$ & $\begin{array}{l}0.076 \\
24,517\end{array}$ & $\begin{array}{l}0.075 \\
24,629\end{array}$ & $\begin{array}{l}0.076 \\
24,517\end{array}$ & $\begin{array}{l}0.076 \\
24,517\end{array}$ & $\begin{array}{l}0.074 \\
21,495\end{array}$ \\
\hline FD * Global PE Growth & $\begin{array}{l}0.022 * * * \\
(0.008)\end{array}$ & $\begin{array}{l}0.027 * * \\
(0.013)\end{array}$ & $\begin{array}{l}0.063 * * * \\
(0.019)\end{array}$ & $\begin{array}{l}0.071 * \\
(0.039)\end{array}$ & $\begin{array}{l}0.043 * * \\
(0.019)\end{array}$ \\
\hline $\begin{array}{r}\text { FD } * \text { Investment } \\
\text { Lumpiness }\end{array}$ & $\begin{array}{l}0.218 * * * \\
(0.06)\end{array}$ & $\begin{array}{l}0.440 * * * \\
(0.137)\end{array}$ & $\begin{array}{l}0.220 * * \\
(0.11)\end{array}$ & $\begin{array}{l}0.667 * * * \\
(0.24)\end{array}$ & $\begin{array}{l}0.384 \\
(0.503)\end{array}$ \\
\hline $\begin{array}{l}\mathrm{R}^{2} \\
\mathrm{~N}\end{array}$ & $\begin{array}{l}0.078 \\
26,514\end{array}$ & $\begin{array}{l}0.078 \\
26,653\end{array}$ & $\begin{array}{l}0.078 \\
26,514\end{array}$ & $\begin{array}{l}0.078 \\
26,514\end{array}$ & $\begin{array}{l}0.075 \\
23,187\end{array}$ \\
\hline FD * Global PE Growth & $\begin{array}{l}0.026 * * * \\
(0.008)\end{array}$ & $\begin{array}{l}0.034 * * \\
(0.013)\end{array}$ & $\begin{array}{l}0.071 * * * \\
(0.019)\end{array}$ & $\begin{array}{l}0.092 * * \\
(0.041)\end{array}$ & $\begin{array}{l}0.046^{* * *} \\
(0.02)\end{array}$ \\
\hline $\mathrm{FD} * \mathrm{EFD}$ & $\begin{array}{l}0.070^{*} \\
(0.039)\end{array}$ & $\begin{array}{l}0.131 * \\
(0.073)\end{array}$ & $\begin{array}{l}0.086 \\
(0.081)\end{array}$ & $\begin{array}{l}0.226 \\
(0.184)\end{array}$ & $\begin{array}{l}0.447 \\
(0.435)\end{array}$ \\
\hline $\mathrm{R}^{2}$ & 0.077 & 0.076 & 0.077 & 0.077 & 0.075 \\
\hline $\mathrm{N}$ & 26,259 & 26,392 & 26,259 & 26,259 & 22,975 \\
\hline
\end{tabular}

Note: The dependent variable is the time average of annual firm-level External Finance Use (EFU) defined as change in shareholders' capital plus change in a firm's long-term debt plus change in a firm's other noncurrent liabilities scaled by total assets. The average is taken over years in which a firm is present in the sample within the 1996-2005 period. Panel A uses US Growth while Panel B is based on Global PE Growth (see Table 6 notes for definitions of these variables). R\&D Intensity, Investment Lumpiness, and External Finance Dependence (EFD) are defined as in Table 7. All specifications are linear regressions with outliers removed (observations outside the 1-to-99 percentile range of the dependent variable), include a constant, firm-level controls (see Table 5 notes for their definitions), and 3-digit ISIC industry and country dummies. *,**, and *** denote significance at the $10 \%, 5 \%$, and $1 \%$ level, respectively, based on robust standard errors clustered at the industry-country level. 
Table 9: Financial Development and External Finance Use: Decomposition

\begin{tabular}{|c|c|c|c|c|c|}
\hline & $\begin{array}{c}\text { Total } \\
\text { Capitalization }\end{array}$ & $\begin{array}{l}\text { Private } \\
\text { Credit }\end{array}$ & $\begin{array}{c}\text { Market } \\
\text { Capitalization }\end{array}$ & $\begin{array}{c}\text { Market } \\
\text { Value Traded }\end{array}$ & $\begin{array}{c}\text { Accounting } \\
\text { Standards }\end{array}$ \\
\hline & \multicolumn{5}{|c|}{ Panel A: Changes in Shareholders' Equity } \\
\hline FD * US Growth & $\begin{array}{l}0.009 * * \\
(0.004)\end{array}$ & $\begin{array}{l}0.013 * * \\
(0.006)\end{array}$ & $\begin{array}{l}0.017 * * \\
(0.008)\end{array}$ & $\begin{array}{l}0.032 * * \\
(0.015)\end{array}$ & $\begin{array}{l}0.049 * * * \\
(0.018)\end{array}$ \\
\hline $\mathrm{R}^{2}$ & 0.070 & 0.070 & 0.071 & 0.070 & 0.070 \\
\hline $\mathrm{N}$ & 24,642 & 24,764 & 24,642 & 24,642 & 21,781 \\
\hline FD * Global PE Growth & $0.005^{*}$ & 0.006 & $0.016 * *$ & 0.015 & $0.016 * *$ \\
\hline $\begin{array}{l}\mathrm{R}^{2} \\
\mathrm{~N}\end{array}$ & $\begin{array}{l}(0.003) \\
0.069 \\
24,642\end{array}$ & $\begin{array}{l}(0.004) \\
0.069 \\
24,764\end{array}$ & $\begin{array}{l}(0.008) \\
0.069 \\
24,642\end{array}$ & $\begin{array}{l}(0.013) \\
0.069 \\
24,642\end{array}$ & $\begin{array}{l}(0.007) \\
0.068 \\
21,781\end{array}$ \\
\hline $\mathrm{N}$ & \multicolumn{5}{|c|}{ Panel B: Changes in Long-Term Debt } \\
\hline FD * US Growth & $\begin{array}{l}0.017 * * * \\
(0.006)\end{array}$ & $\begin{array}{l}0.029 * * \\
(0.012)\end{array}$ & $\begin{array}{l}0.029 * * \\
(0.012)\end{array}$ & $\begin{array}{l}0.067 * * * \\
(0.023)\end{array}$ & $\begin{array}{l}0.071 * \\
(0.042)\end{array}$ \\
\hline $\mathrm{R}^{2}$ & 0.094 & 0.094 & 0.094 & 0.094 & 0.089 \\
\hline $\mathrm{N}$ & 24,642 & 24,764 & 24,642 & 24,642 & 21,781 \\
\hline FD * Global PE Growth & $0.013 * *$ & $0.016^{*}$ & $0.039 * * *$ & 0.038 & 0.019 \\
\hline & $(0.006)$ & $(0.008)$ & $(0.014)$ & $(0.029)$ & $(0.014)$ \\
\hline $\mathrm{R}^{2}$ & 0.093 & 0.093 & 0.094 & 0.093 & 0.087 \\
\hline \multirow[t]{2}{*}{$\mathrm{N}$} & 25,709 & 25,845 & 25,709 & 25,709 & 22,711 \\
\hline & \multicolumn{5}{|c|}{ Panel C: Changes in Other Non-Current Liabilities } \\
\hline FD * US Growth & $\begin{array}{l}0.004 \\
(0.005)\end{array}$ & $\begin{array}{l}0.014 \\
(0.01)\end{array}$ & $\begin{array}{l}-0.005 \\
(0.007)\end{array}$ & $\begin{array}{l}0.017 \\
(0.019)\end{array}$ & $\begin{array}{l}-0.002 \\
(0.027)\end{array}$ \\
\hline $\mathrm{R}^{2}$ & 0.037 & 0.037 & 0.037 & 0.037 & 0.032 \\
\hline $\mathrm{N}$ & 24,639 & 24,761 & 24,639 & 24,639 & 21,780 \\
\hline FD * Global PE Growth & 0.003 & 0.006 & 0.004 & 0.012 & -0.001 \\
\hline & $(0.004)$ & $(0.007)$ & $(0.008)$ & $(0.019)$ & $(0.01)$ \\
\hline $\mathrm{R}^{2}$ & 0.037 & 0.037 & 0.037 & 0.037 & 0.032 \\
\hline \multirow[t]{2}{*}{$\mathrm{N}$} & 25,706 & 25,842 & 25,706 & 25,706 & 22,710 \\
\hline & \multicolumn{5}{|c|}{ Panel D: Changes in Total Non-Current Liabilities } \\
\hline FD $*$ US Growth & $\begin{array}{l}0.018 * * \\
(0.008)\end{array}$ & $\begin{array}{l}0.041 * * * \\
(0.014)\end{array}$ & $\begin{array}{l}0.018 \\
(0.014)\end{array}$ & $\begin{array}{l}0.077 * * * \\
(0.029)\end{array}$ & $\begin{array}{l}0.048 \\
(0.047)\end{array}$ \\
\hline $\mathrm{R}^{2}$ & 0.070 & 0.069 & 0.070 & 0.070 & 0.066 \\
\hline $\mathrm{N}$ & 24,642 & 24,764 & 24,642 & 24,642 & 21,781 \\
\hline FD * Global PE Growth & $0.017 * *$ & $0.023 * *$ & $0.043 * *$ & 0.056 & 0.018 \\
\hline & $(0.007)$ & $(0.011)$ & $(0.016)$ & $(0.034)$ & $(0.017)$ \\
\hline $\mathrm{R}^{2}$ & 0.070 & 0.069 & 0.070 & 0.070 & 0.066 \\
\hline $\mathrm{N}$ & 25,709 & 25,845 & 25,709 & 25,709 & 22,711 \\
\hline
\end{tabular}

Note: The dependent variable in Panel A, B, C, and D is the time average of annual firm-level changes in shareholders' capital, in a firm's long-term debt, in a firm's other non-current liabilities, and in a firm's total non-current liabilities, respectively. The averages are taken over years in which a firm is present in the sample within the 1996-2005 period and are scaled by total assets. Total non-current liabilities equal longterm debt plus other non-current liabilities. See Table 6 notes for definitions of US Growth and Global PE Growth. All specifications are linear regressions with outliers removed (observations outside the 1-to-99 percentile range of the dependent variable), include a constant, firm-level controls (see Table 5 notes for their definitions), and 3-digit ISIC industry and country dummies. ***, and *** denote significance at the $10 \%, 5 \%$, and $1 \%$ level, respectively, based on robust standard errors clustered at the industry-country level. 
Table A.1a: Definitions and Sources of Variables

\begin{tabular}{|c|c|}
\hline Name & Definition and Source \\
\hline \multicolumn{2}{|r|}{ Firm-Level Variables } \\
\hline Total Assets & $\begin{array}{l}\text { Firm's total assets (TOAS) in EUR billions. We use the value from the } \\
\text { first year a firm enters the sample within the 1996-2005 period. Source: } \\
\text { Amadeus. }\end{array}$ \\
\hline Employees & $\begin{array}{l}\text { Number of employees (EMPL) scaled down by } 10,000 \text {. We use the value } \\
\text { from the first year a firm enters the sample within the 1996-2005 period. } \\
\text { Source: Amadeus. }\end{array}$ \\
\hline Age & $\begin{array}{l}\text { The number of years since a firm's incorporation, scaled down by } 100 \text {. We } \\
\text { use the value from the first year a firm enters the sample within the 1996- } \\
2005 \text { period. Source: Amadeus. }\end{array}$ \\
\hline $\begin{array}{l}\text { External Finance } \\
\text { Use }\end{array}$ & $\begin{array}{l}\text { First, we sum the year-on-year change in shareholders' capital }\left(C A P I_{t}-\right. \\
\left.C A P I_{t-1}\right) \text {, the year-on-year change in firm's long-term debt }\left(L T D B_{t}-\right. \\
\left.L T D B_{t-1}\right) \text {, and the year-on-year change in firm's other non-current liabilities } \\
\left(O N C L I_{t}-O N C L I_{t-1}\right) \text {. The result is scaled by total assets from the } \\
\text { beginning of each year }\left(T O A S_{t-1}\right) \text {. Second, we compute the time average of } \\
\text { annual measures from the first step over the years in which a firm is present } \\
\text { in the sample within the } 1996-2005 \text { period. Source: Amadeus. }\end{array}$ \\
\hline Leverage & $\begin{array}{l}\text { Defined as long-term debt (LTDB) plus current liabilities (CULI) divided by } \\
\text { total assets (TOAS). We use the value from the first year a firm enters the } \\
\text { sample within the 1996-2005 period. Source: Amadeus. }\end{array}$ \\
\hline Tangibility & $\begin{array}{l}\text { Defined as fixed assets (FIAS) divided by total assets (TOAS). We use the } \\
\text { value from the first year a firm enters the sample within the 1996-2005 } \\
\text { period. Source: Amadeus. }\end{array}$ \\
\hline Collateral & $\begin{array}{l}\text { Defined as fixed assets (FIAS) plus inventories (STOK) plus accounts } \\
\text { receivables (DEBT) divided by total assets (TOAS). We use the value from } \\
\text { the first year a firm enters the sample within the 1996-2005 period. Source: } \\
\text { Amadeus. }\end{array}$ \\
\hline Cash & $\begin{array}{l}\text { Defined as cash holdings (CASH) divided by total assets (TOAS). We use } \\
\text { the value from the first year a firm enters the sample. Source: Amadeus. }\end{array}$ \\
\hline Quoted & $\begin{array}{l}\text { 0/1 variable, equal } 1 \text { if a firm is a publicly listed company and } 0 \text { otherwise. } \\
\text { Source: Amadeus. }\end{array}$ \\
\hline
\end{tabular}


Table A.1b: Definitions and Sources of Variables

\begin{tabular}{|c|c|}
\hline Name & Definition and Source \\
\hline \multicolumn{2}{|r|}{ Industry-Level Variables } \\
\hline R\&D Intensity & $\begin{array}{l}\text { First, for each Compustat firm, we compute the time average of R\&D } \\
\text { expenditures and capital expenditures over the 1996-2005 period and take } \\
\text { the ratio of the two averages. Second, we take the ratio from the first step of } \\
\text { the median US firm for each 3-digit ISIC industry. Source: Compustat. }\end{array}$ \\
\hline $\begin{array}{l}\text { Investment } \\
\text { Lumpiness }\end{array}$ & $\begin{array}{l}\text { First, for each Compustat firm, we compute the average number of } \\
\text { investment spikes it experienced over the 1996-2005 period. An investment } \\
\text { spike is defined as an event when annual capital expenditure exceeds } 30 \\
\text { percent of the firm's stock of fixed assets. Second, we take the average of the } \\
\text { statistic computed in the first step for each US 3-digit ISIC industry Source: } \\
\text { Compustat. }\end{array}$ \\
\hline $\begin{array}{l}\text { External Finance } \\
\text { Dependence }\end{array}$ & $\begin{array}{l}\text { First, for each Compustat firm, we sum capital expenditures and cash flows } \\
\text { from operations over the 1996-2005 period. Second, for each Compustat } \\
\text { firm, we compute the ratio of capital expenditures minus cash flows from } \\
\text { operations over capital expenditures using the sums obtained in the first step. } \\
\text { Third, we take the ratio from the second step of the median US firm for each } \\
\text { 3-digit ISIC industry. Source: Compustat. }\end{array}$ \\
\hline US Growth & $\begin{array}{l}\text { First, we compute year-on-year growth rates by taking the difference of } \\
\text { natural logarithms of annual real value added for each US 2-digit ISIC } \\
\text { industry. Second, for each firm in our sample, we compute the time average } \\
\text { of year-on-year growth rates over the same years for which External Finance } \\
\text { Use is computed. Source: OECD STAN. }\end{array}$ \\
\hline Global PE Level & $\begin{array}{l}\text { First, we take the world price-to-earnings ratios of industry portfolios as they } \\
\text { are defined in Datastream. Second, for each firm in our sample, we compute } \\
\text { the time average of the world price-to-earnings ratios over the same years } \\
\text { for which External Finance Use is computed. Finally, we match Datastream } \\
\text { industries into 2-digit ISIC. Source: Datastream. }\end{array}$ \\
\hline Global PE Growth & $\begin{array}{l}\text { First, we compute year-on-year growth rates of the world price-to-earnings } \\
\text { ratio of industry portfolios as they are defined in Datastream. Second, for } \\
\text { each firm in our sample, we compute the time average of the year-on- } \\
\text { year growth rates over the same years for which External Finance Use is } \\
\text { computed. Finally, we match Datastream industries to 2-digit ISIC. Source: } \\
\text { Datastream. }\end{array}$ \\
\hline
\end{tabular}


Table A.1c: Definitions and Sources of Variables

\begin{tabular}{|c|c|}
\hline Name & Definition and Source \\
\hline \multicolumn{2}{|r|}{ Country-Level Variables } \\
\hline Total Capitalization & $\begin{array}{l}\text { Private credit by deposit money banks and other financial institutions plus } \\
\text { stock market capitalization divided by GDP in } 1996 \text {. Source: Beck et al. } \\
(2000) \text {. }\end{array}$ \\
\hline Private Credit & $\begin{array}{l}\text { Private credit by deposit money banks and other financial institutions divided } \\
\text { by GDP in 1996. Source: Beck et al. (2000). }\end{array}$ \\
\hline $\begin{array}{l}\text { Market } \\
\text { Capitalization }\end{array}$ & $\begin{array}{l}\text { Stock market capitalization divided by GDP in } 1996 \text {. Source: Beck et al. } \\
(2000) \text {. }\end{array}$ \\
\hline $\begin{array}{l}\text { Market Value } \\
\text { Traded }\end{array}$ & $\begin{array}{l}\text { Stock market total value traded divided by GDP in } 1996 \text {. Source: Beck et al. } \\
(2000) \text {. }\end{array}$ \\
\hline & $\begin{array}{l}\text { Index created by examining and rating companies' } 1990 \text { annual reports } \\
\text { on their inclusion or omission of } 90 \text { items in balance sheets and income }\end{array}$ \\
\hline Accounting & statements and published by the Center for International Financial Analysis \\
\hline Standards & $\begin{array}{l}\& \text { Research, Inc. The maximum is } 90 \text {, the minimum } 0 \text {, and we scaled it down } \\
\text { by 100. Source: The Center for International Financial Analysis \& Research. }\end{array}$ \\
\hline $\begin{array}{l}\text { Government Bank } \\
\text { Ownership }\end{array}$ & $\begin{array}{l}\text { Share of the top } 10 \text { banks' assets owned by a country's government in } 1995 \text {. } \\
\text { The percentage of the assets owned by the government in a given bank is } \\
\text { calculated by multiplying the share of each shareholder in that bank by } \\
\text { the share the government owns in that shareholder, and then summing the } \\
\text { resulting ownership stakes. Source: La Porta et al. (2002). }\end{array}$ \\
\hline $\begin{array}{l}\text { Government Bank } \\
\text { Control }\end{array}$ & $\begin{array}{l}\text { Share of the top } 10 \text { banks' assets controlled by a country's government at the } \\
50 \text { percent level in } 1995 \text {. The percentage of assets owned by the government } \\
\text { in a given bank is calculated following the same methodology outlined for } \\
\text { Government Bank Ownership. Source: La Porta et al. (2002). }\end{array}$ \\
\hline Overhead Costs & $\begin{array}{l}\text { Accounting value of banks' overhead costs as a share of their total assets. } \\
\text { Scaled up by } 100 \text {. Source: Beck et al. (2000). }\end{array}$ \\
\hline Net Interest Margin & $\begin{array}{l}\text { Accounting value of banks' net interest revenue as a share of their interest- } \\
\text { bearing assets. Scaled up by } 100 \text {. Source: Beck et al. (2000). }\end{array}$ \\
\hline Control Premium & $\begin{array}{l}\text { Control premium estimated by Dyck and Zingales (2004) using the sample } \\
\text { of } 393 \text { controlling blocks sales in 1990-2000 period. We use the estimated } \\
\text { country fixed effects from Table III, column (1). }\end{array}$ \\
\hline
\end{tabular}


Table A.2: Financial Development and External Finance Use: Robustness Checks

\begin{tabular}{|c|c|c|c|c|c|}
\hline & $\begin{array}{c}\text { Total } \\
\text { Capitalization }\end{array}$ & $\begin{array}{l}\text { Private } \\
\text { Credit }\end{array}$ & $\begin{array}{c}\text { Market } \\
\text { Capitalization }\end{array}$ & $\begin{array}{c}\text { Market } \\
\text { Value Traded }\end{array}$ & $\begin{array}{c}\text { Accounting } \\
\text { Standards }\end{array}$ \\
\hline & \multicolumn{5}{|c|}{ Panel A: Limited Liability Companies Only } \\
\hline FD * US Growth & $\begin{array}{l}0.025 * * \\
(0.01)\end{array}$ & $\begin{array}{l}0.050 * * * \\
(0.016)\end{array}$ & $\begin{array}{l}0.031 \\
(0.02)\end{array}$ & $\begin{array}{l}0.098 * * \\
(0.042)\end{array}$ & $\begin{array}{l}0.074 \\
(0.064)\end{array}$ \\
\hline $\mathrm{R}^{2}$ & 0.082 & 0.081 & 0.081 & 0.082 & 0.08 \\
\hline $\mathrm{N}$ & 17,099 & 17,223 & 17,099 & 17,099 & 15,129 \\
\hline \multirow[t]{2}{*}{ FD * Global PE Growth } & $0.027 * * *$ & $0.034 * *$ & $0.071 * * *$ & $0.105 * * *$ & $0.044 *$ \\
\hline & $(0.009)$ & $(0.014)$ & $(0.019)$ & $(0.039)$ & $(0.023)$ \\
\hline $\mathrm{R}^{2}$ & 0.081 & 0.08 & 0.082 & 0.081 & 0.079 \\
\hline \multirow[t]{2}{*}{$\mathrm{N}$} & 17,879 & 18,017 & 17,879 & 17,879 & 15,820 \\
\hline & \multicolumn{5}{|c|}{ Panel B: Only Industries with at Least 20 Firms } \\
\hline FD * US Growth & $\begin{array}{l}0.032 * * \\
(0.014)\end{array}$ & $\begin{array}{l}0.081 * * * \\
(0.03)\end{array}$ & $\begin{array}{l}0.039^{*} \\
(0.023)\end{array}$ & $\begin{array}{l}0.128 * * * \\
(0.048)\end{array}$ & $\begin{array}{l}0.141 * * * \\
(0.055)\end{array}$ \\
\hline $\mathrm{R}^{2}$ & 0.071 & 0.072 & 0.071 & 0.071 & 0.071 \\
\hline $\mathrm{N}$ & 24,024 & 24,024 & 24,024 & 24,024 & 21,507 \\
\hline \multirow[t]{2}{*}{ FD * Global PE Growth } & $0.030 * * *$ & $0.045^{* * *}$ & $0.071 * * *$ & $0.097 * *$ & $0.052 * * *$ \\
\hline & $(0.009)$ & $(0.014)$ & $(0.019)$ & $(0.041)$ & $(0.019)$ \\
\hline $\mathrm{R}^{2}$ & 0.071 & 0.071 & 0.072 & 0.071 & 0.071 \\
\hline \multirow[t]{2}{*}{$\mathrm{N}$} & 25085 & 25085 & 25085 & 25085 & 22441 \\
\hline & \multicolumn{5}{|c|}{ Panel C: Controlling for Industry-Period Fixed Effects } \\
\hline FD * US Growth & $\begin{array}{l}0.028 * * * \\
(0.011)\end{array}$ & $\begin{array}{l}0.055^{* * *} * \\
(0.016)\end{array}$ & $\begin{array}{l}0.039 * \\
(0.022)\end{array}$ & $\begin{array}{l}0.121 * * * \\
(0.041)\end{array}$ & $\begin{array}{l}0.097 \\
(0.061)\end{array}$ \\
\hline $\mathrm{R}^{2}$ & 0.080 & 0.079 & 0.080 & 0.080 & 0.079 \\
\hline $\mathrm{N}$ & 25,419 & 25,544 & 25,419 & 25,419 & 22,239 \\
\hline FD * Global PE Growth & $0.041 * * *$ & $0.053 * * *$ & $0.102 * * *$ & $0.139 * * *$ & $0.054 * *$ \\
\hline & $(0.009)$ & $(0.015)$ & $(0.02)$ & $(0.044)$ & $(0.025)$ \\
\hline $\mathrm{R}^{2}$ & 0.080 & 0.079 & 0.080 & 0.080 & 0.078 \\
\hline \multirow[t]{2}{*}{$\mathrm{N}$} & 26,526 & 26,665 & 26,526 & 26,526 & 23,196 \\
\hline & \multicolumn{5}{|c|}{ Panel D: Median Regressions } \\
\hline FD * US Growth & $\begin{array}{l}0.008 \\
(0.007)\end{array}$ & $\begin{array}{l}0.017 \\
(0.017)\end{array}$ & $\begin{array}{l}0.01 \\
(0.014)\end{array}$ & $\begin{array}{l}0.009 \\
(0.029)\end{array}$ & $\begin{array}{l}0.021 * * \\
(0.01)\end{array}$ \\
\hline Pseudo- $\mathrm{R}^{2}$ & 0.038 & 0.037 & 0.038 & 0.038 & 0.036 \\
\hline $\mathrm{N}$ & 25,419 & 25,544 & 25,419 & 25,419 & 22,239 \\
\hline \multirow[t]{2}{*}{ FD * Global PE Growth } & 0.008 & 0.012 & 0.017 & 0.009 & $0.021 *$ \\
\hline & $(0.005)$ & (0.009) & $(0.014)$ & $(0.029)$ & $(0.011)$ \\
\hline Pseudo- $\mathrm{R}^{2}$ & 0.038 & 0.038 & 0.038 & 0.038 & 0.036 \\
\hline $\mathrm{N}$ & 26,526 & 26,665 & 26,526 & 26,526 & 23,196 \\
\hline
\end{tabular}

Note: The dependent variable is the time average of annual firm-level External Finance Use (EFU) defined as in Table 5. We re-estimate the basic specification from table 6 on the sub-sample of companies with limited and limited liability legal forms in Panel A. Panel B restricts sample to ISIC 2-digit industrycountry pairs with at least 20 firms available. Panel C presents estimates obtained while controlling for firm specific industry-period fixed effects, where period is defined by the availability of annual External Finance Use. Panel D presents estimates obtained from median regressions. Except Panel D, all specifications are linear regressions with outliers removed (observations outside the 1-to-99 percentile range of the dependent variable), include a constant, firm-level controls (see Table 5 notes for their definitions), and country and (with the exception of panel C) 3-digit ISIC industry dummies. *, **, and *** denote significance at the $10 \%, 5 \%$, and $1 \%$ level, respectively, based on robust standard errors clustered at the industry-country level in Panels A, B and C and on bootstrapped standard errors clustered at the industrycountry level in Panel D. 
Table A.3: Growth Opportunities and Measurement Error

\begin{tabular}{|c|c|c|c|c|c|}
\hline & $\begin{array}{c}\text { Total } \\
\text { Capitalization }\end{array}$ & $\begin{array}{l}\text { Private } \\
\text { Credit }\end{array}$ & $\begin{array}{c}\text { Market } \\
\text { Capitalization }\end{array}$ & $\begin{array}{c}\text { Market } \\
\text { Value Traded }\end{array}$ & $\begin{array}{c}\text { Accounting } \\
\text { Standards }\end{array}$ \\
\hline & \multicolumn{5}{|c|}{ Panel A : Instrumenting by Global PE Growth } \\
\hline FD * US Growth & $\begin{array}{l}0.152 * * * \\
(0.054)\end{array}$ & $\begin{array}{l}0.225^{* * *} \\
(0.097)\end{array}$ & $\begin{array}{l}0.284 * * * \\
(0.106)\end{array}$ & $\begin{array}{l}0.443 * * \\
(0.209)\end{array}$ & $\begin{array}{l}0.601 * * \\
(0.304)\end{array}$ \\
\hline $\mathrm{R}^{2}$ & 0.068 & 0.071 & 0.066 & 0.074 & 0.069 \\
\hline \multirow[t]{2}{*}{$\mathrm{N}$} & 25,419 & 25,544 & 25,419 & 25,419 & 22,239 \\
\hline & \multicolumn{5}{|c|}{ First-Stage Regression Statistics: } \\
\hline Partial $\mathrm{R}^{2}$ & 0.042 & 0.038 & 0.056 & 0.043 & 0.032 \\
\hline F-statistics & 23.41 & 15.71 & 14.07 & 23.46 & 23.74 \\
\hline \multirow[t]{2}{*}{ p-value } & 0.000 & 0.000 & 0.000 & 0.000 & 0.000 \\
\hline & \multicolumn{5}{|c|}{ Panel B : Instrumenting by US Growth } \\
\hline FD * Global PE Growth & $\begin{array}{l}0.107 * * * \\
(0.038)\end{array}$ & $\begin{array}{l}0.196 * * * \\
(0.061)\end{array}$ & $\begin{array}{l}0.161^{*} \\
(0.083)\end{array}$ & $\begin{array}{l}0.498 * * * \\
(0.173)\end{array}$ & $\begin{array}{l}0.172 \\
(0.11)\end{array}$ \\
\hline $\mathrm{R}^{2}$ & 0.071 & 0.066 & 0.076 & 0.069 & 0.073 \\
\hline \multirow[t]{2}{*}{$\mathrm{N}$} & 25,419 & 25,544 & 25,419 & 25,419 & 22,239 \\
\hline & \multicolumn{5}{|c|}{ First-Stage Regression Statistics: } \\
\hline Partial $\mathrm{R}^{2}$ & 0.042 & 0.038 & 0.056 & 0.043 & 0.032 \\
\hline F-statistics & 61.32 & 58.00 & 39.99 & 62.65 & 28.52 \\
\hline p-value & 0.000 & 0.000 & 0.000 & 0.000 & 0.000 \\
\hline
\end{tabular}

Note: The dependent variable is the time average of annual firm-level External Finance Use (EFU) defined as in Table 5. In Panel A, FD * US Growth is instrumented by FD* Global PE Growth, while in Panel B FD * Global PE Growth is instrumented by FD* US Growth (see Table 6 notes for definitions of these variables). F-statistics is the test of the significance of instrument in first stage regression and it's p-value is reported in parentheses. All specifications have outliers removed (observations outside the 1-to-99 percentile range of the dependent variable), include a constant, firm-level controls (see Table 5 notes for their definitions), and 3-digit ISIC industry and country dummies. ***, and *** denote significance at the $10 \%, 5 \%$, and $1 \%$ level, respectively, based on robust standard errors clustered at the industry-country level. 
Table A.4: Financial Development and External Finance Use: Alternative Growth Opportunities

\begin{tabular}{|c|c|c|c|c|c|}
\hline Country & $\begin{array}{c}\text { Total Capitalization * } \\
\text { VA Growth }\end{array}$ & S.D. & $\mathrm{R}^{2}$ & $\mathrm{~N}$ & $\begin{array}{c}\text { Total } \\
\text { Capitalization }\end{array}$ \\
\hline AT & $0.035 * * *$ & (0.009) & 0.076 & 26,589 & 1.07 \\
\hline $\mathrm{BE}$ & -0.006 & $(0.016)$ & 0.076 & 24,964 & 1.15 \\
\hline $\mathrm{CA}$ & 0.011 & $(0.016)$ & 0.077 & 24,768 & 1.64 \\
\hline $\mathrm{CH}$ & 0.008 & $(0.012)$ & 0.076 & 26,732 & 3.02 \\
\hline $\mathrm{CZ}$ & 0.007 & $(0.005)$ & 0.076 & 25,632 & 0.93 \\
\hline $\mathrm{DE}$ & $0.023 *$ & $(0.012)$ & 0.075 & 26,046 & 1.29 \\
\hline DK & $0.018 * *$ & $(0.008)$ & 0.077 & 26,732 & 0.65 \\
\hline ES & -0.000 & $(0.016)$ & 0.078 & 23,575 & 1.06 \\
\hline FI & -0.002 & $(0.010)$ & 0.074 & 25,986 & 1.02 \\
\hline FR & $0.026 * * *$ & $(0.008)$ & 0.081 & 21,778 & 1.19 \\
\hline GR & 0.005 & $(0.010)$ & 0.068 & 25,989 & 0.49 \\
\hline HU & $0.008 *$ & $(0.005)$ & 0.076 & 26,627 & 0.29 \\
\hline IS & -0.005 & $(0.007)$ & 0.074 & 26,486 & 0.60 \\
\hline IT & -0.029 & $(0.023)$ & 0.079 & 21,465 & 0.73 \\
\hline JP & 0.010 & $(0.010)$ & 0.077 & 25,419 & 2.76 \\
\hline $\mathrm{KR}$ & $0.013 *$ & $(0.007)$ & 0.077 & 25,419 & 1.41 \\
\hline LU & $0.024 * * *$ & $(0.007)$ & 0.073 & 23,958 & 2.60 \\
\hline NL & 0.019 & $(0.020)$ & 0.077 & 26,300 & 4.21 \\
\hline NO & -0.005 & $(0.014)$ & 0.074 & 19,691 & 1.13 \\
\hline PT & -0.002 & $(0.007)$ & 0.077 & 26,200 & 0.92 \\
\hline SE & $0.007 *$ & $(0.004)$ & 0.077 & 25,104 & 1.82 \\
\hline SK & $-0.013 * *$ & $(0.005)$ & 0.076 & 26,625 & 0.47 \\
\hline US & $0.028 * * *$ & $(0.010)$ & 0.078 & 25,419 & 2.57 \\
\hline
\end{tabular}

Note: The dependent variable is the time average of annual firm-level External Finance Use (EFU) defined as in Table 5. We re-estimate the basic specification from table 5 by replacing VA Growth of US industries with VA Growth of industries located in a set of OECD countries. Each row of the table corresponds to the regression where industry-specific VA Growth comes from a country given in first column, with observations from this country dropped. We report value of estimated coefficient on the interaction of Total Capitalization and VA Growth of industries in a given country, it's standard deviation, $\mathrm{R}^{2}$ of a regression and Number of observations. Last column reports Total Capitalization of a country given in first column. All specifications are linear regressions with outliers removed (observations outside the 1to-99 percentile range of the dependent variable), include a constant, firm-level controls (see Table 5 notes for their definitions), and country and 3-digit ISIC industry dummies. *,**, and *** denote significance at the $10 \%, 5 \%$, and $1 \%$ level, respectively, based on robust standard errors clustered at the industry-country level. 


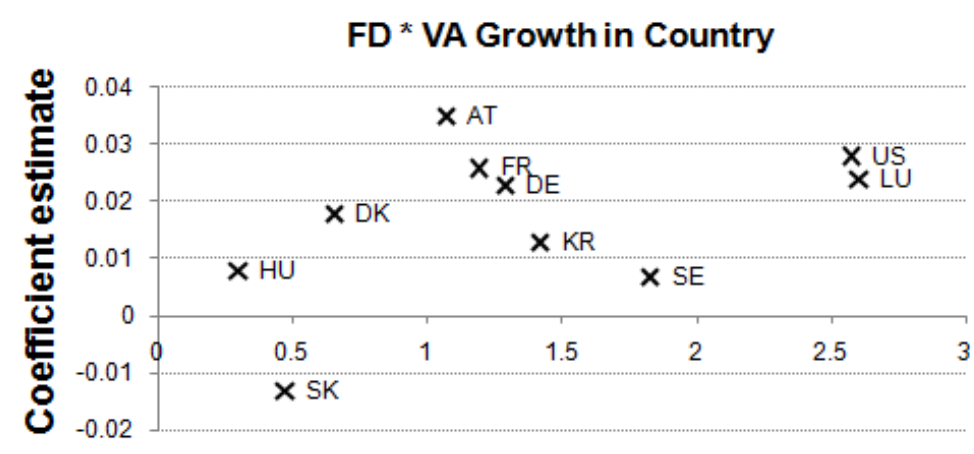

Total Capitalization

Figure 1: Industry growth rates in selected OECD countries as alternative proxies for growth opportunities

\section{FD* US Growth}

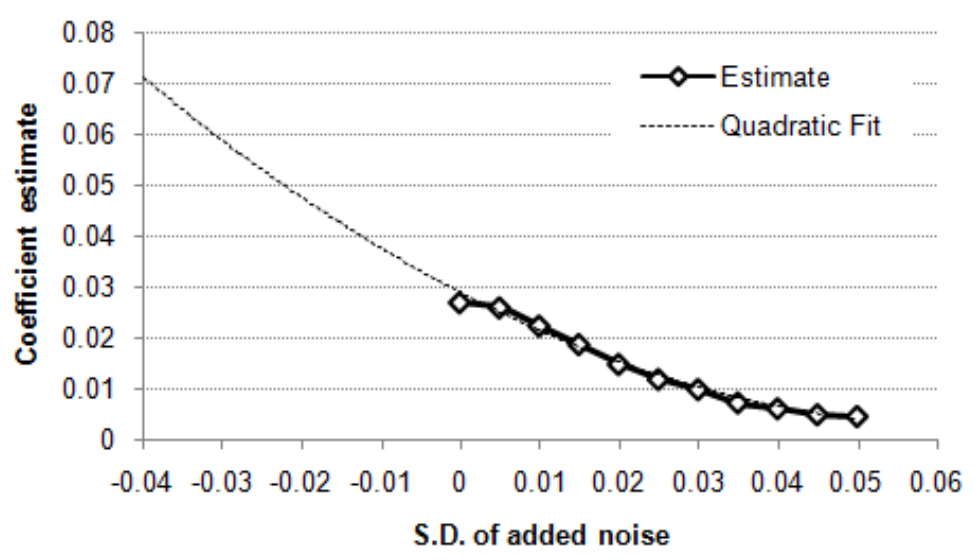

FD* GlobalPE Growth

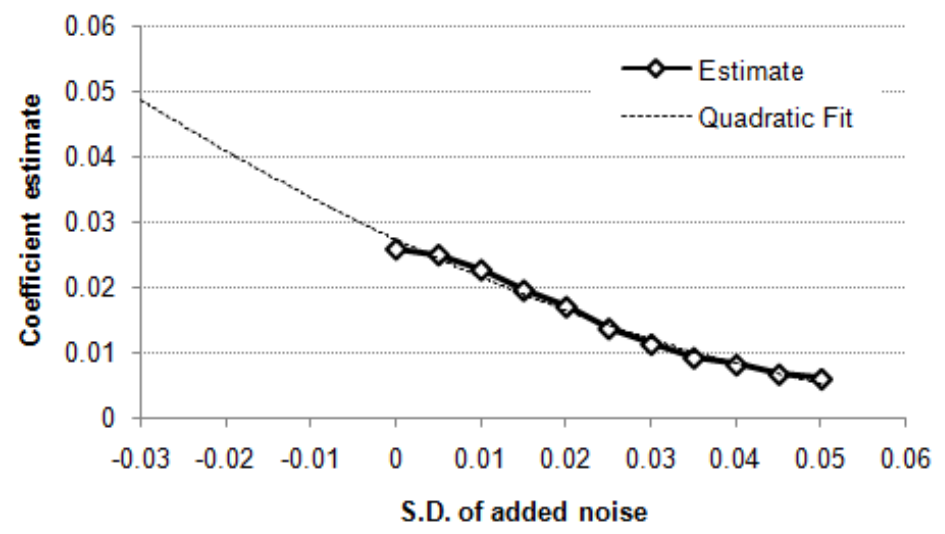

Figure 2: Sensitivity of estimates to added noise in $G O_{i}$ 
Table A.5: Alternative Measures of Financial Development

\begin{tabular}{lccccc}
\hline & $\begin{array}{c}\text { Gov. Bank } \\
\text { Ownership }\end{array}$ & $\begin{array}{c}\text { Gov. Bank } \\
\text { Control }\end{array}$ & $\begin{array}{c}\text { Overhead } \\
\text { Costs }\end{array}$ & $\begin{array}{c}\text { Net. Int. } \\
\text { Margin }\end{array}$ & $\begin{array}{c}\text { Control } \\
\text { Premium }\end{array}$ \\
\cline { 2 - 6 } FD * US Growth & -0.014 & -0.002 & -0.006 & -0.001 & $-0.085^{* * *}$ \\
& $(0.038)$ & $(0.037)$ & $(0.007)$ & $(0.007)$ & $(0.04)$ \\
$\mathrm{R}^{2}$ & 0.074 & 0.074 & 0.073 & 0.073 & 0.065 \\
$\mathrm{~N}$ & 25,196 & 25,196 & 23,454 & 23,454 & 20,871 \\
$\mathrm{FD} *$ Global PE growth & $-0.076^{* *}$ & $-0.071^{* *}$ & $-0.007 * *$ & $-0.006^{*}$ & -0.049 \\
& $(0.033)$ & $(0.033)$ & $(0.004)$ & $(0.003)$ & $(0.051)$ \\
$\mathrm{R}^{2}$ & 0.074 & 0.074 & 0.073 & 0.073 & 0.065 \\
$\mathrm{~N}$ & 26,288 & 26,288 & 24,500 & 24,500 & 21,799 \\
\hline
\end{tabular}

Note: The dependent variable is the time average of annual firm-level External Finance Use (EFU) defined as in Table 5. Country-level measures of Financial Development (FD) are predetermined; see Table A.1c for their complete definitions and sources. US Growth and Global PE Growth are as in Table 6. All specifications are linear regressions with outliers removed (observations outside the 1-to-99 percentile range of the dependent variable), include a constant, firm-level controls (see Table 5 notes for their definitions), and 3-digit ISIC industry and country dummies. *, **, and *** denote significance at the $10 \%, 5 \%$, and $1 \%$ level, respectively, based on robust standard errors clustered at the industry-country level. 


\section{A Balance Sheet Definition of External Finance Use}

Rajan and Zingales (1998) define external finance dependence $(E F D)$ as the share of capital expenditure $(C E)$ not financed by cash flow $(C F)$

$$
E F D_{t}=\frac{C E_{t}-C F_{t}}{C E_{t}}
$$

To measure External Finance Use (our main dependent variable), we find an analogy to their defition using balance sheet data that are available for most firms in our sample. In a panel of annual firm balance sheet items, we can approximate capital expenditure by the change in fixed assets (FIAS) plus depreciation (DEPRE)

$$
\begin{aligned}
C E_{t} & =\left(F I A S_{t}-F I A S_{t-1}\right)+D E P R E_{t} \\
& =\Delta F I A S_{t}+D E P R E_{t} .
\end{aligned}
$$

Cash flow is approximated by firm's net profit $(P L$, measured after taxes and interest payments) increased by depreciation (depreciation is cost but not cash outflow) and adjusted for the change in the net working capital. An increase in current assets $(C U A S)$ uses cash while an increase in current liabilities $(C U L I)$ releases cash

$$
\begin{aligned}
C F_{t} & =P L_{t}+D E P R E_{t}-\left(C U A S_{t}-C U A S_{t-1}\right)+\left(C U L I_{t}-C U L I_{t-1}\right) \\
& =P L_{t}+D E P R E_{t}-\Delta C U A S_{t}+\Delta C U L I_{t} .
\end{aligned}
$$

Next, we show how is difference $C E_{t}-C F_{t}$ related to the amount of external finance raised. The fundamental balance sheet identity necessitates that change in total assets equals change in equity plus change in liabilities. Decomposing total assets into fixed assets (FIAS), current assets (CUAS, i.e. inventories and accounts receivables), and cash $(C A S H)$; and decomposing total liabilities into shareholders' equity (CAPI), other 
shareholders' funds (OSFD, i.e. reserves and retained earnings), long-term debt ( $L T D B)$, other non-current liabilities (ONCLI, i.e. provisions), and current liabilities (CULI, i.e. short-term loans and accounts payables), the balance sheet identity becomes

$\Delta F I A S_{t}+\Delta C U A S_{t}+\Delta C A S H_{t}=\Delta C A P I_{t}+\Delta O S F D_{t}+\Delta L T D B_{t}+\Delta O N C L I_{t}+\Delta C U L I_{t}$.

Using the above equations we can rewrite difference $C E_{t}-C F_{t}$ as

$$
\begin{aligned}
& C E_{t}-C F_{t}=\Delta F I A S_{t}+D E P R E_{t}-P L_{t}-D E P R E_{t}+\Delta C U A S_{t}-\Delta C U L I_{t} \\
& =\Delta F I A S_{t}+\Delta C U A S_{t}-P L_{t}-\Delta C U L I_{t} \\
& =\underbrace{\Delta C A P I_{t}+\Delta L T D B_{t}+\Delta O N C L I_{t}}_{=E F U_{t}(\text { ExternalFinanceUse })}-\underbrace{\left(P L_{t}-\Delta O S F D_{t}\right)}_{=\text {DIV }(\text { Dividends })}-\Delta C A S H_{t}(\mathrm{~A}-3)
\end{aligned}
$$

Term $\triangle C A P I_{t}+\triangle L T D B_{t}+\triangle O N C L I_{t}$ stands for the amount of equity raised/repurchased $\left(\triangle C A P I_{t}\right)$ plus the amount of long-term debt issued/repaid $\left(\triangle L T D B_{t}\right)$ plus the change in other forms of long-term financing $\left(\triangle O N C L I_{t}\right)$. If a firm pays dividend $(D I V)$, the corresponding change in other shareholders' funds is $O S F D_{t}-O S F D_{t-1}=P L_{t}-D I V_{t}$, and term $P L_{t}-\triangle O S F D_{t}$ in (A-3) is equal to dividends paid to shareholders. If a firm does not pay any dividends, $D I V_{t}=0$, and the stock of cash does not change, $\Delta C A S H_{t}=0$, the difference between capital expenditure and cash flow from operations is equal to the amount of equity and long-term financing raised

$$
C E_{t}-C F_{t}=\Delta C A P I_{t}+\Delta L T D B_{t}+\Delta O N C L I_{t} .
$$

We define External Finance Use (EFU) as $\triangle C A P I_{t}+\Delta L T D B_{t}+\Delta O N C L I_{t}$ and we verify that equation (A-3) holds in our data when we use (A-1) and (A-2) to compute the lefthand side. We deviate from Rajan and Zingales (1998) to the extent that we scale $E F U$ by total assets as of the beginning of each year $\left(T O A S_{t-1}\right)$. The main technical reason is that capital expenditure is close to zero for many firms, which makes division difficult. We scale by total assets because it proxies for firm size and it is the measure that is the most comparable across firms in our sample. 
Individual researchers, as well as the on-line and printed versions of the CERGE-EI Working Papers (including their dissemination) were supported from the European Structural Fund (within the Operational Programme Prague Adaptability), the budget of the City of Prague, the Czech Republic's state budget and the following institutional grants:

- Center of Advanced Political Economy Research [Centrum pro pokročilá politickoekonomická studia], No. LC542, (2005-2009),

- Economic Aspects of EU and EMU Entry [Ekonomické aspekty vstupu do Evropské unie a Evropské měnové unie], No. AVOZ70850503, (2005-2010);

- Economic Impact of European Integration on the Czech Republic [Ekonomické dopady evropské integrace na ČR], No. MSM0021620846, (2005-2011);

Specific research support and/or other grants the researchers/publications benefited from are acknowledged at the beginning of the Paper.

(c) Jan Bena and Peter Ondko, 2009

All rights reserved. No part of this publication may be reproduced, stored in a retrieval system or transmitted in any form or by any means, electronic, mechanical or photocopying, recording, or otherwise without the prior permission of the publisher.

Published by

Charles University in Prague, Center for Economic Research and Graduate Education (CERGE) and

Economics Institute ASCR, v. v. i. (EI)

CERGE-El, Politických vězňů 7, 11121 Prague 1, tel.: +420 224005 153, Czech Republic.

Printed by CERGE-EI, Prague

Subscription: CERGE-EI homepage: http://www.cerge-ei.cz

Editors: Directors of CERGE and EI

Managing editors: Deputy Directors for Research of CERGE and EI

ISSN 1211-3298

ISBN 978-80-7343-200-3 (Univerzita Karlova. Centrum pro ekonomický výzkum

a doktorské studium)

ISBN 978-80-7344-189-0 (Národohospodářský ústav AV ČR, v. v. i.) 
CERGE-EI

P.O.BOX 882

Politických vězňů 7

11121 Praha 1

Czech Republic http://www.cerge-ei.cz 